Louisiana State University

LSU Digital Commons

8-1-2009

\title{
Phylogeny and phylogenetic classification of the antbirds, ovenbirds, woodcreepers, and allies (Aves: Passeriformes: Infraorder Furnariides)
}

\author{
Robert G. Moyle \\ American Museum of Natural History \\ R. Terry Chesser \\ Smithsonian National Museum of Natural History \\ Robb T. Brumfield \\ Louisiana State University \\ Jose G. Tello \\ American Museum of Natural History \\ Daniel J. Marchese \\ American Museum of Natural History
}

See next page for additional authors

Follow this and additional works at: https://digitalcommons.Isu.edu/biosci_pubs

\section{Recommended Citation}

Moyle, R., Chesser, R., Brumfield, R., Tello, J., Marchese, D., \& Cracraft, J. (2009). Phylogeny and phylogenetic classification of the antbirds, ovenbirds, woodcreepers, and allies (Aves: Passeriformes: Infraorder Furnariides). Cladistics, 25 (4), 386-405. https://doi.org/10.1111/j.1096-0031.2009.00259.x

This Article is brought to you for free and open access by the Department of Biological Sciences at LSU Digital Commons. It has been accepted for inclusion in Faculty Publications by an authorized administrator of LSU Digital Commons. For more information, please contact ir@lsu.edu. 
Authors

Robert G. Moyle, R. Terry Chesser, Robb T. Brumfield, Jose G. Tello, Daniel J. Marchese, and Joel Cracraft 


\title{
Cladistics
}

Cladistics 25 (2009) 386-405

$10.1111 / \bar{j} .1096-0031.2009 .00259 . x$

\section{Phylogeny and phylogenetic classification of the antbirds, ovenbirds, woodcreepers, and allies (Aves: Passeriformes: infraorder Furnariides)}

\author{
Robert G. Moyle ${ }^{\mathrm{a}, \mathrm{b}, *}$, R. Terry Chesser ${ }^{\mathrm{c}}$, Robb T. Brumfield ${ }^{\mathrm{d}}$, Jose G. Tello ${ }^{\mathrm{a}, \mathrm{e}}$, \\ Daniel J. Marchese ${ }^{\mathrm{a}}$ and Joel Cracraft ${ }^{\mathrm{a}}$
}

\begin{abstract}
${ }^{a}$ Department of Ornithology, American Museum of Natural History, Central Park West at 79th St, New York, NY 10024, USA; ${ }^{b}$ Department of Ecology and Evolutionary Biology and Biodiversity Research Center, University of Kansas, Lawrence, KS 66045, USA; ${ }^{c}$ US Geological Survey Patuxent Wildlife Research Center, National Museum of Natural History, Smithsonian Institution, PO Box 37012, Washington, DC 20013, USA; ${ }^{d}$ Museum of Natural Science and Department of Biological Sciences, Louisiana State University, Baton Rouge, LA 70803, USA and ${ }^{e}$ Department of Biology, Long Island University, Brooklyn, NY 11201, USA
\end{abstract}

Accepted 4 March 2009

\begin{abstract}
The infraorder Furnariides is a diverse group of suboscine passerine birds comprising a substantial component of the Neotropical avifauna. The included species encompass a broad array of morphologies and behaviours, making them appealing for evolutionary studies, but the size of the group (ca. 600 species) has limited well-sampled higher-level phylogenetic studies. Using DNA sequence data from the nuclear RAG-1 and RAG-2 exons, we undertook a phylogenetic analysis of the Furnariides sampling 124 (more than $88 \%$ ) of the genera. Basal relationships among family-level taxa differed depending on phylogenetic method, but all topologies had little nodal support, mirroring the results from earlier studies in which discerning relationships at the base of the radiation was also difficult. In contrast, branch support for family-rank taxa and for many relationships within those clades was generally high. Our results support the Melanopareidae and Grallariidae as distinct from the Rhinocryptidae and Formicariidae, respectively. Within the Furnariides our data contradict some recent phylogenetic hypotheses and suggest that further study is needed to resolve these discrepancies. Of the few genera represented by multiple species, several were not monophyletic, indicating that additional systematic work remains within furnariine families and must include dense taxon sampling. We use this study as a basis for proposing a new phylogenetic classification for the group and in the process erect new family-group names for clades having high branch support across methods.
\end{abstract}

(c) The Willi Hennig Society 2009.

The infraorder Furnariides (new name, following proposed rank-suffixes of Sibley et al., 1988; equivalent to Furnariida of Irestedt et al., 2002; and Ericson et al., $2003 a, b)$ is a large Neotropical clade of about 600 species that encompasses a diverse array of morphologies and behaviours. The group, although more speciesrich and abundant in tropical forests, occurs in all major South American habitats, including montane forest, arid scrub, and wetlands, and some taxa (e.g. the Furnarii-

*Corresponding author: E-mail address: moyle@ku.edu dae) are richly represented in the temperate regions of southern South America. The ovenbirds (Furnariidae, 236 species) are small, generally brown (or sometimes grey) insectivores, well known for their diversity of nest architecture (e.g. Zyskowski and Prum, 1999). Woodcreepers (Dendrocolaptidae, 52 species) are adapted for bark clinging and probing and have long bills and stiffened tail rachises. Typical antbirds (Thamnophilidae, 209 species) have converged on common avian ecomorphologies, as revealed by the English names of some subgroups, such as antshrikes, antvireos, and antwrens. Ground-antbirds (here termed Grallariidae, 
63 species) include species of two distinct ecomorphologies, the long-legged terrestrial antpittas and the more arboreal antthrushes. The gnateaters (Conopophagidae, eight species) are small stocky birds of the forest understorey, and the tapaculos (Rhinocryptidae, 55 species) are secretive terrestrial species with short wings and tails and long tarsi. Male gnateaters (in all but one species) are characterized by a striking white or silvery postocular stripe (or tuft).

The Furnariides have long been considered a cohesive evolutionary unit. All species in the group have a unique tracheophone syrinx (Ames, 1971), and monophyly of the Furnariides has been supported by several molecular studies (Sibley and Ahlquist, 1985, 1990; Irestedt et al., 2001, 2002; Chesser, 2004). Relationships among and within families, as well as phylogenetic affinities of some unusual taxa, have been the focus of most molecular studies of the group. Two studies used a combination of nuclear and mitochondrial DNA sequence data to reconstruct higher-level relationships within the parvorders Thamnophilida + Furnariida (names after Sibley et al., 1988) (Irestedt et al., 2002) and, more generally, the entire New World suboscine clade (Chesser, 2004). Although the two studies included only a small number of species relative to the size of the group, and thus had few taxa in common, they converged on some of the same conclusions, identifying well-supported core clades and placing some aberrant genera within that phylogenetic framework. Strong bootstrap support in both studies indicated that the family "Furnariidae" as previously delimited (Vaurie, 1971, 1980) is not monophyletic if the Dendrocolaptidae are excluded; moreover, two "furnariid" genera (Geositta and Sclerurus) are basal to a sister-pairing of the Dendrocolaptidae and all other furnariid species (Fig. 1). Branching basally from the furnariid/dendrocolaptid clade were three clades with largely unresolved relationships, the Rhinocryptidae (minus Melanopareia) and two clades traditionally associated with a family-level taxon, the Formicariidae. Neither study recovered a monophyletic Formicariidae. Basal nodes in both studies were weakly supported, although both found the Thamnophilidae, Conopophagidae, and the rhinocryptid genus Melanopareia to be basal to all other taxa. Support for the monophyly of most higher-level taxa, except as noted above, was high. These studies, together with others (e.g. Rice, 2005a, b), indicated that the infraorder Furnariides, as delimited here, consists of the following major groupings: Thamnophilidae (typical antbirds), Melanopareidae (crescentchests of the genus Melanopareia), Conopophagidae (gnateaters of the genus Conopophaga and antpittas of the genus Pittasoma), Grallariidae (antpittas of the genera Grallaria, Myrmothera, Grallaricula, and Hylopezus), Rhinocryptidae (tapaculos excluding Melanopareia), Formicariidae (antthrushes, comprising the genera Formicarius and Chamaeza), Scleruridae (Sclerurus + Geositta), Dendrocolaptidae (woodcreepers), and the Furnariidae (ovenbirds).

Other recent studies have addressed relationships within families and produced some unexpected results. Irestedt et al. (2004a) analysed DNA sequences from a mitochondrial gene and two nuclear introns from representatives of the Thamnophilidae. Four genera (Terenura, Myrmornis, Pygiptila, and Thamnistes) formed a clade that was sister to all other taxa. The rest of the family was split into two clades: (i) the antshrikes, antvireos, and Herpsilochmus antwrens, and (ii) all other taxa. Brumfield et al. (2007) analysed

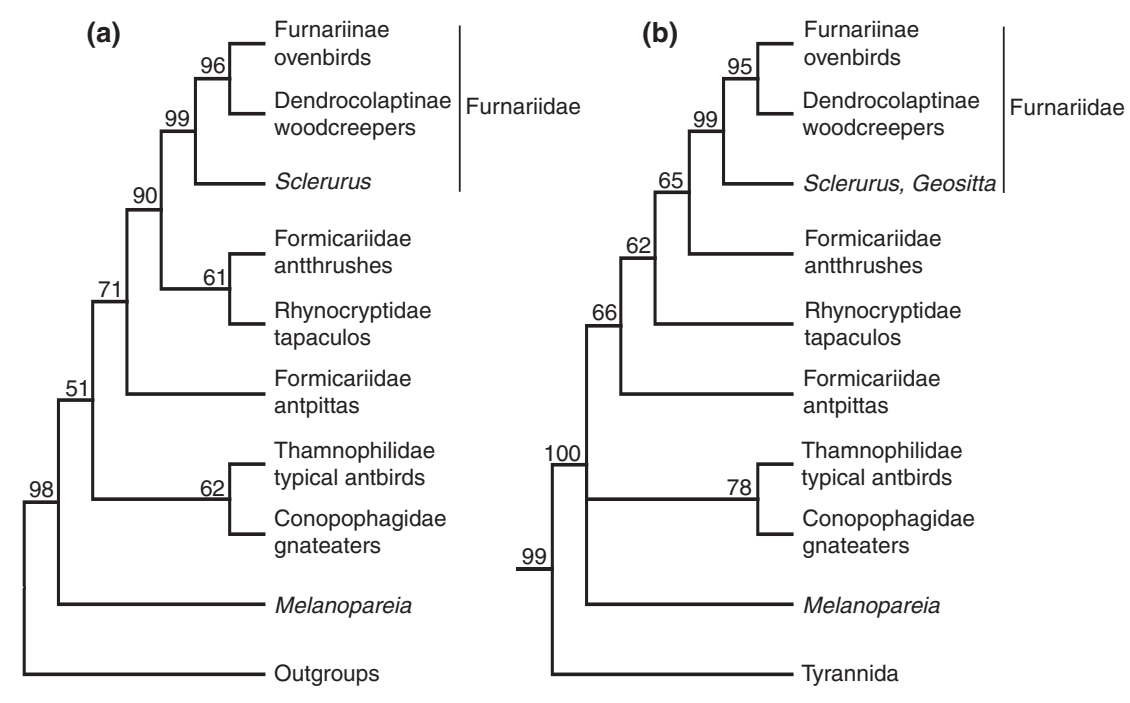

Fig. 1. Summary of recent higher-level molecular phylogenetic results for the Furnariides. (a) Maximum-parsimony analysis of three nuclear and one mitochondrial marker, with bootstraps proportions by nodes from Irestedt et al. (2002). (b) Maximum-likelihood analysis of a nuclear intron, with bootstrap proportions by nodes from Chesser (2004). 
sequences from three mitochondrial genes and one nuclear intron in 70 thamnophilid species. They found Terenura to be sister to a large clade of all other taxa, within which a clade of Myrmornis, Pygiptila, and Thamnistes was basal. Irestedt et al. (2004b) used one intron and one mitochondrial gene to assess congruence between molecular and morphological data (Feduccia, 1973; Raikow, 1994) in the woodcreepers. Notable relationships recovered by the molecular data included a basal position for Glyphorynchus and relatively distal positions for Nasica and Drymornis. Morphological data had indicated that Nasica and Drymornis were the two basal lineages in the family (Raikow, 1994) and that Glyphorynchus was embedded well within the radiation (Feduccia, 1973; Raikow, 1994). Fjeldså et al. (2005) and Irestedt et al. (2006), using the same set of markers as Irestedt et al. (2004b), examined relationships within their Furnariidae and Dendrocolaptinae to identify adaptational shifts within this diverse clade. One of their most important findings was that Xenops, traditionally considered to be an ovenbird, was the basal branch in the woodcreeper clade. They re-interpreted morphological evolution within the group and concluded that parallel evolution between woodcreepers and woodpeckers had occurred early in woodcreeper diversification, and that some morphological characters associated with vertical tree-climbing were subsequently lost in some woodcreepers.

Although these studies have advanced our ideas about major lineages within Furnariides and provided insight into the systematics of particular families, no comprehensive phylogenetic hypothesis for the group as a whole has been proposed. Relationships among major lineages remain unresolved, perhaps due to sparse taxon sampling in previous higher-level studies and the use of sequences of relatively rapidly evolving mitochondrial genes and nuclear introns. In the present study, we analysed more than $4 \mathrm{~kb}$ of nuclear exon sequence from more than $90 \%$ of the described genera. The combination of dense taxon sampling and a large matrix of slowly evolving nuclear DNA sequences allowed us to achieve a level of phylogenetic detail and support not possible in previous work. This new phylogenetic resolution, moreover, permits a re-evaluation of the classification of these large groups, and we present a phylogenetic classification for these taxa.

\section{Materials and methods}

\section{Taxon and character sampling}

We sampled individuals from each furnariine genus for which fresh tissue was available (Appendix S1). Single species were used as exemplars for most genera, although selected genera suspected of being polyphyletic were represented by additional species. Previous molecular analyses (e.g. Barker et al., 2002, 2004; Ericson et al., 2002) strongly supported a basal topology for Passeriformes in which the oscine passerines are sister to all suboscines. Therefore, the oscine Cyanocitta cristata was used as the outgroup taxon in all analyses. Taxa from the two other suboscine clades-the New World Tyrannides (Tyrannus tyrannus and Pipra coronata), which is the sister-group to the Thamnophilida + Furnariida, and the Old World Eurylaimides (Pitta oatesi and Smithornis capensis) - were included in the analyses to provide a better anchor for basal splits in the two clades of this study.

We sequenced two exons of the nuclear recombination activating gene (RAG-1 and RAG-2) for all taxa. These gene regions have been used extensively in higher level avian systematic studies (e.g. Groth and Barrowclough, 1999; Barker et al., 2002, 2004; Beresford et al., 2005; Moyle et al., 2006), and are effective at elucidating relationships at a variety of taxonomic levels. Genomic DNA was extracted from muscle tissue using proteinase $\mathrm{K}$ digestion following the manufacturer's protocol (DNeasy tissue kit, Qiagen, Valencia, USA). The exons were amplified using a variety of primer pairs from Groth and Barrowclough (1999) and Barker et al. (2002, 2004). We purified PCR products with Perfectprep PCR cleanup kits (Eppendorf). Purified PCR products were sequenced with BigDye Terminator Cycle Sequencing kits (Applied Biosystems, Foster City, USA). Primers used for PCR were also used for cycle sequencing reactions, resulting in bi-directional sequence for all taxa. Cycle sequencing products were run out on an ABI Prism 3100 automated DNA Sequencer (Perkin-Elmer Applied Biosystems). The computer program Sequencher 4.1 (Genecodes, Ann Arbor, USA) was used to reconcile chromatograms of complementary fragments and to align sequences across taxa.

\section{Phylogenetic analysis}

Prior to analysis, we used the incongruence length difference (ILD) test (Farris et al., 1994, 1995) implemented in PAUP*4.0b10 (Swofford, 2003) to explore for congruence of phylogenetic signal between the two genes (the efficacy of this test is discussed in the next section). Due to the size of the data matrix, we chose phylogenetic methods that searched the tree space both thoroughly and efficiently, and we also made an effort to evaluate concordance among analytical approaches. We implemented a maximum-parsimony (MP)-based analysis along with model-based analyses including both maximum likelihood (ML) and Bayesian inference (BI). All parsimony searches used equal weighting of characters. In searching for the shortest tree we employed the parsimony-ratchet method of Nixon (1999), which traverses large portions of tree-space by re-weighting a 
subset of the characters. Successive iterations of this technique allow a large number of tree islands to be sampled. Using Pauprat (Sikes and Lewis, 2001), we constructed batch files that were then implemented in Paup*4.0b10 (Swofford, 2003). The batch files directed 20 independent runs of 5000 ratchet iterations. We also ran three independent heuristic searches in Paup*, each with 100 random taxon addition replicates and tree bisection reconnection (TBR) branch swapping. All most parsimonious trees from the heuristic searches as well as the trees from ratchet iterations were imported back into Paup* and filtered to remove duplicates and non-MP trees (from some ratchet iterations). A strict consensus tree was constructed from this set of most parsimonious trees. Support for nodes in the MP consensus tree was assessed with non-parametric bootstrapping (5000 replicates, ten random taxon addition replicates, five trees saved at each replication) implemented in the program TNT ver. 1.0 (Goloboff et al., 2008).

Prior to the ML analysis we used Modeltest 3.7 (Posada and Crandall, 1998) to determine the appropriate model of evolution and to estimate parameter values. From the Modeltest output we used the model and parameter estimates indicated by the Akaike Information Criterion (AIC, Posada and Buckley, 2004). An ML estimate of phylogeny was produced with Paup* (heuristic search, TBR branch swapping, one replicate starting from a neighbour-joining tree reconstructed from a matrix of p-distances) as well as with the program Phyml (Guindon and Gascuel, 2003). Phyml utilizes a hill climbing approach that simultaneously adjusts the topology, branch lengths, and model parameters to maximize the likelihood. With heuristic algorithms, especially those designed for fast estimation of large data sets, there is a concern that searches may get stuck in local optima and not find the tree island with the highest likelihood. We therefore ran five independent Phyml searches to see if they converged on the same topology and likelihood score. Branch support for the ML topology was assessed with 500 non-parametric bootstrap replicates in Phyml.

The Bayesian analysis used a Metropolis-coupled Markov-chain Monte Carlo (MCMCMC) method to sample the posterior distribution of tree topologies and parameters. In a majority rule consensus tree constructed from a large set of sampled trees, the frequency of node occurrence should approximate the probability of that node existing, given the data and prior probabilities ( $\mathrm{BP}=$ nodal posterior probabilities of Fig. 2). For large data sets, Bayesian analysis has been considered to be particularly attractive because it is more computationally feasible than traditional ML methods. However, there are problems in the implementation of Bayesian methods in phylogenetics and in interpretation of the results (see below).

We performed Bayesian analysis with MrBayes 3.1.2 (Ronquist and Huelsenbeck, 2003), using two simulta- neous runs of four chains each. Initial runs of two million generations employed default program settings and were used to assess convergence and mixing and to estimate branch lengths. Differential heating allows the heated Markov chains to travel more efficiently between isolated peaks in tree and parameter space. It is important to use an appropriate heating parameter that will ensure thorough searching of tree space, but also allow switching between chains. The temperature parameter for heating the chains (temp) was adjusted until the acceptance rates for swaps between chains fell between 0.10 and 0.70 .

An integral but contentious aspect of Bayesian phylogenetic analysis is the inclusion of prior probabilities in the likelihood equation. Thus, probability distributions for all parameters, including topology, branch lengths, and substitution models, must be specified before the analysis. Sensitivity of the posterior distribution to prior probabilities has received much attention, and in most instances the prior probabilities are swamped by information in the data matrix (Rannala and Yang, 1996; Huelsenbeck et al., 2002; Brandley et al., 2006). Recently, however, particular concern has been raised over the potential influence of branch-length priors (Lewis et al., 2005; Yang and Rannala, 2005). One issue is that some prior probability distributions may bias posterior distributions when short internodes are expected. Visual inspection of trees in the posterior distribution of preliminary Bayesian runs indicated that short internal nodes were common, especially in deeper portions of the tree. Because of this we experimented with three different branch-length priors. First, we used the default branchlength prior in MrBayes 3.1.1 (exponential with a mean of $0.10)$. Next, we used exponential priors with means equal to (i) the average branch-length of all edges in the preliminary trees, or (ii) the average of only the internal edges (Lewis et al., 2005).

An important feature of Bayesian inference is the ability to allow different models of evolution and different model parameters for subsets of the data (Ronquist and Huelsenbeck, 2003; Nylander et al., 2004). We used Bayes factors to choose between partitioning schemes and to avoid over-parameterization of the data (see Brandley et al., 2005 for a discussion of the methodology and rationale). We ran analyses using all data in a single partition, two partitions (by gene), three partitions (by codon position), and six partitions (by gene and by codon position). Bayes factors were calculated using the harmonic mean from the sump command within MrBayes. The appropriate number of model parameters was determined by running MrModeltest 2.2 (Nylander, 2004) on each data partition.

After the appropriate data-partitioning scheme and evolutionary models were chosen and branch-length priors and heating parameters were estimated, we performed two runs of four chains for ten million 
(a)

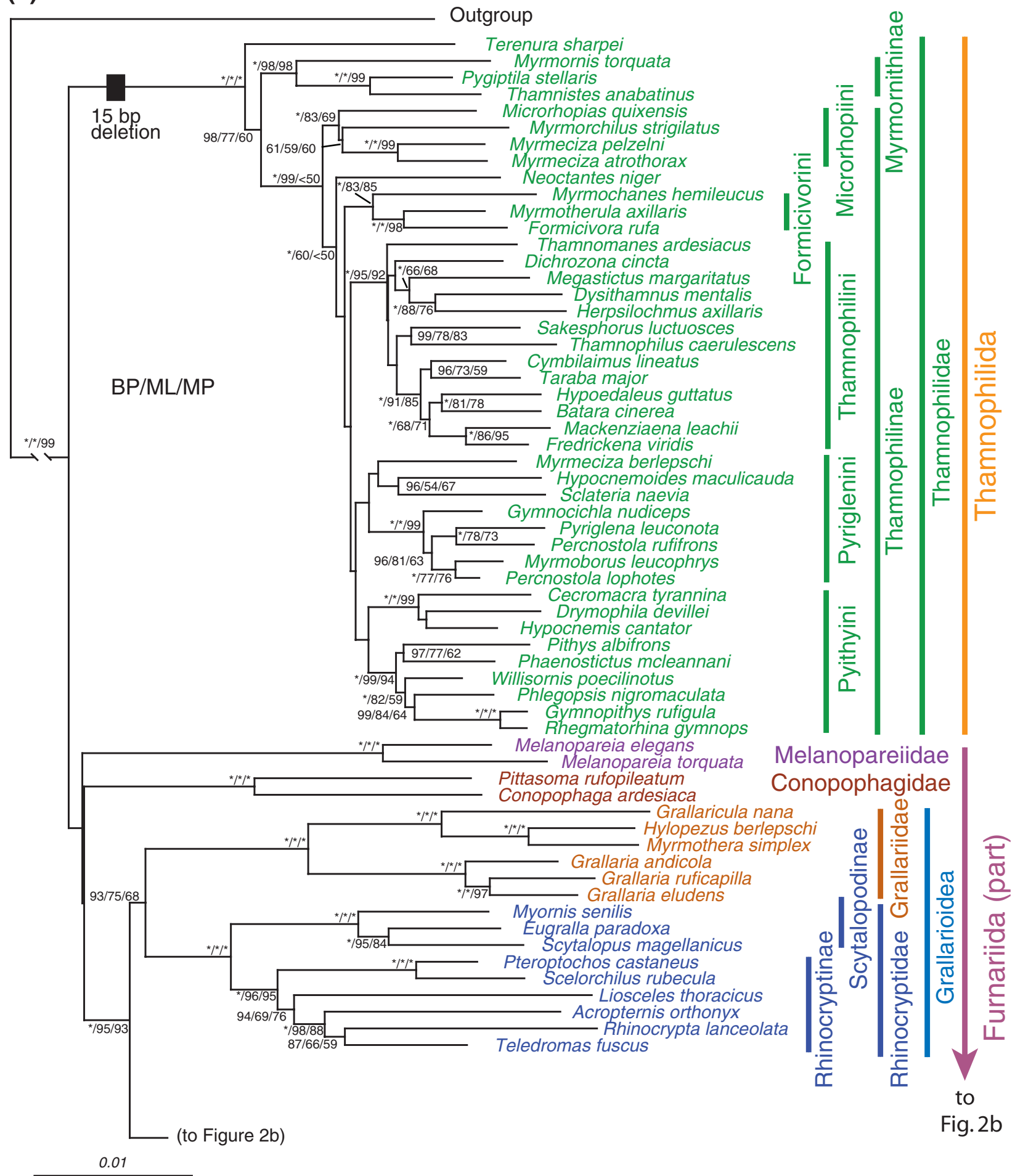

Fig. 2. Phylogenetic analysis of the Furnariides. Maximum-likelihood tree from analysis of the combined RAG-1 and RAG-2 data set. Numbers for clades indicate Bayesian posterior-probability/maximum-likelihood bootstrap support/maximum-parsimony bootstrap support, all expressed as a percentage. Asterisks indicate $100 \%$ posterior probability or bootstrap support. Nodes that were not recovered by a particular method are represented by a dash. Bars and labels to the right and colour coding highlight taxonomic groupings proposed in the present paper. 
(b)

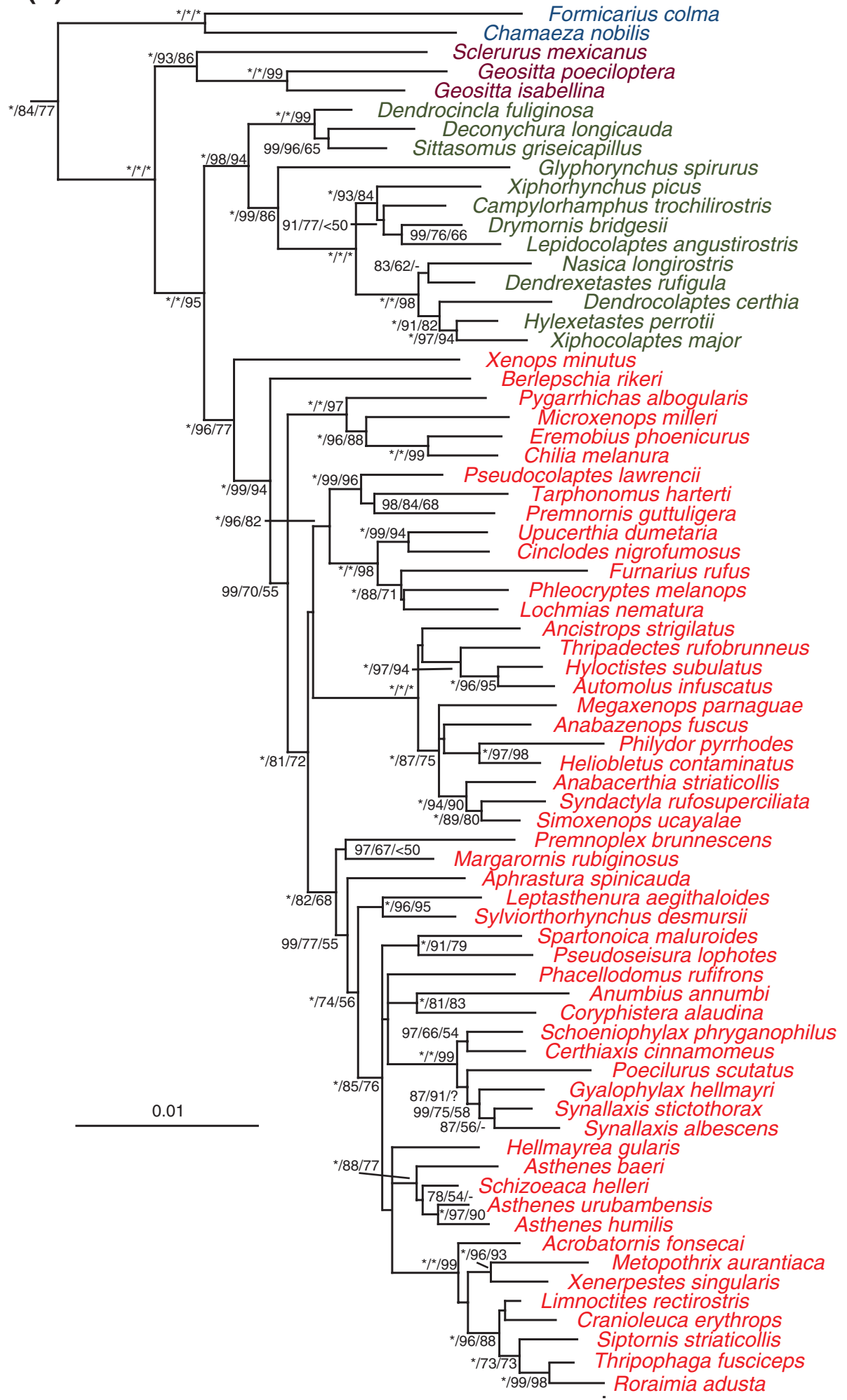

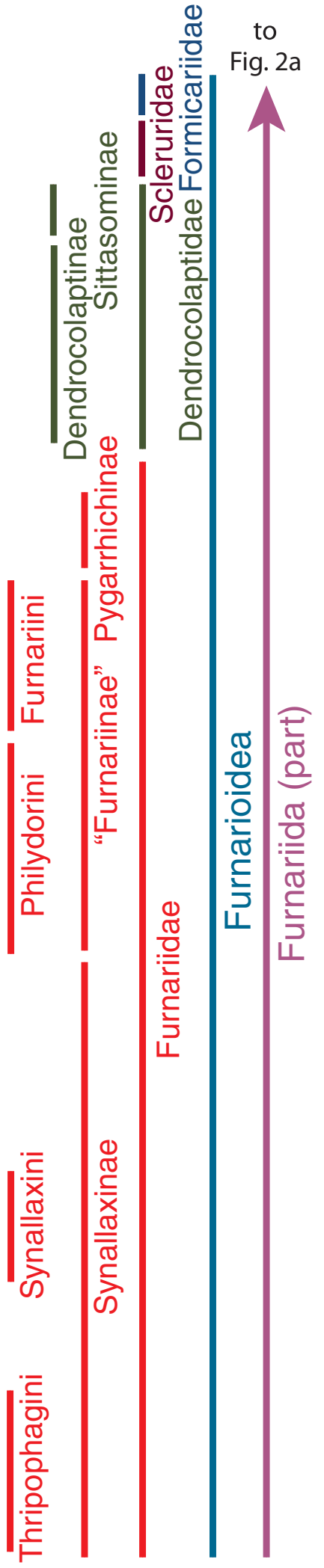

Fig. 2b. (Continued). 
generations. The burn-in phases of the runs were identified by visual inspection of likelihood/generation plots and the average standard deviation of split frequencies, a metric produced by MrBayes by comparing the results of two simultaneous runs. Burn-in generations were discarded, the remaining trees from the two runs were combined into a single file, and a majority rule consensus tree was constructed.

\section{Results}

\section{Data characteristics}

The final data matrix contained 4024 characters (2872 bp of RAG-1, 1154 bp of RAG-2) and 139 taxa (134 ingroup, five outgroup). New sequences produced for this study are available from GenBank (FJ460973FJ461228). Of the total characters, 1695 were variable and 1111 of these were parsimony informative. Full RAG-1 and RAG-2 sequences were obtained for all taxa except Percnostola lophotes, for which half of the RAG2 sequence could not be obtained cleanly. Base frequencies were biased in favour of adenine $(\mathrm{A}=0.315$, $\mathrm{T}=0.250, \mathrm{G}=0.234, \mathrm{C}=0.201)$, but homogeneous across taxa $\left(\chi^{2}=31.28, P=1.00\right)$.

The partition homogeneity test using each gene as a partition was significant $(P=0.01)$, indicating that the two genes may contain conflicting phylogenetic signal. The two gene regions used in this study are not expected to exhibit some of the attributes known to bias the ILD test, such as disparate levels of homoplasy (Dolphin et al., 2000), uncertain sequence alignments (Messenger and McGuire, 1998), or differences in rate heterogeneity (Barker and Lutzoni, 2002; Darlu and Lecointre, 2002). The appropriate level of significance for $P$-values in ILD tests has been discussed (Sullivan, 1996; Cunningham, $1997 \mathrm{a}, \mathrm{b})$, as has the possibility that the test is a fundamentally flawed estimator of data combinability (Yoder et al., 2001), all casting further doubt on the direct interpretability of ILD $P$-scores. Because we see the ILD test more as a data-exploration tool than as an arbiter of data combinability, we have chosen to use a combined, total-evidence approach. Nonetheless, we decided to investigate further the nature of incongruence by examining the topology produced by analysis of each gene separately before the combined-data analyses were attempted.

We used the program Compat.py (Kauff and Lutzoni, 2002) to identify topological conflicts in Bayesian consensus trees derived from separate analysis of the RAG-1 and RAG-2 data (not shown). Three conflicts existed involving nodes supported by $99 \%$ or greater Bayesian probability (BP), all of which involved the placement of Hypocnemoides maculicauda. The RAG-1 partition placed $H$. maculicauda as sister to Sclateria naevia, embedded well within the thamnophilid radiation. In contrast, the RAG-2 data placed H. maculicau$d a$ near the base of the thamnophilids but with no support for any specific sister relationship. The three conflicts identified by Compat.py were well-supported nested clades that included $H$. maculicauda and $S$. naevia in the RAG-1 tree but lacked $H$. maculicauda in the RAG-2 tree. Nine nodes were identified as conflicting when $95 \%$ or greater posterior probability was used as the cutoff, including the three discussed above. Of the six other conflicts, three also involved the presence of $H$. maculicauda and/or S. naevia in clades. The arrangement recovered in analyses of the RAG-1 data (and the combined data) is corroborated by an independent molecular phylogenetic analysis of thamnophilids that used different molecular markers (Brumfield et al., 2007). The other three conflicts occurred in the furnariid radiation, and involved rearrangements among closely related taxa. The RAG-1 and RAG-2 data each placed Automolus infuscatus, Hyloctistes subulatus, and Thripadectes rufobrunneus in a well-supported clade, but differed as to the arrangement among them. RAG-1 placed Hyloctistes and Automolus as sisters (100 BP) whereas RAG-2 placed Thripadectes and Automolus as sisters $(97 \mathrm{BP})$. All taxa involved in these conflicts were re-sequenced to check for laboratory or labelling errors, but all new sequences matched those used in the original analyses.

\section{Phylogenetic analyses}

As discussed below, all approaches to deciphering relationships yielded virtually identical trees, and all differences were traceable to nodes having very poor branch support. We therefore summarized this topological congruence using the ML tree that shows estimated branch lengths (Fig. 2, discussed in the next section). Here we report the tree statistics for the different analyses.

Three heuristic parsimony searches and 20 5000iteration parsimony-ratchet replicates for the combined data all obtained shortest trees of 4521 steps. Two heuristic searches found 7487 equally most parsimonious trees and the third found 7488 most parsimonious trees. The parsimony-ratchet procedure produced 3037 trees of 4521 steps. When all MP trees from different analyses were loaded into Paup* and filtered to remove duplicates, 7488 trees remained. This indicates that the two search methods and 23 independent analyses (three heuristic searches, 20 ratchet replicates) converged on the same set of most parsimonious trees, evidence that suggests tree space was thoroughly searched. The MP trees had consistency indices of 0.50 , retention indices of 0.77 , and rescaled consistency indices of 0.38 . A strict consensus of the 7488 MP trees was well resolved in most parts of the tree (Appendix S2). 
The AIC in Modeltest determined that the most appropriate evolutionary model for our data had six substitution types, a proportion of sites invariant, and gamma distributed rate variation among sites $(\mathrm{GTR}+\mathrm{I}+\mathrm{G})$. This parameter-rich model was used in ML searches and the Bayesian analysis. A single heuristic search in Paup* using TBR branch swapping and the parameter estimates from Modeltest produced a topology that was very similar to the MP tree $(-\ln L=34443.67)$. Five independent heuristic searches in Phyml produced a single topology with a likelihood score of $-\ln L=34447.44$ (Fig. 2). The ML trees produced by Paup* and Phyml were virtually identical and the difference in likelihood scores may be due in part to differences in the way the two programs handle missing data. Bootstrap re-sampling did not support topological differences between the ML and MP trees.

Preliminary Bayesian analyses identified a heating parameter (temp $=0.05$ ) that resulted in acceptance rates between 0.10 and 0.70 for swaps among chains. This heating parameter was used in all subsequent analyses. From preliminary runs, average branch lengths were estimated to be 0.0047 substitutions per site (all branches) or 0.0023 substitutions per site (internal branches only). Trial runs with each of these values and the default value of 0.10 did not make an appreciable difference in the posterior probabilities of clades. For the long runs the average length of internal branches was used [prset brlenspr $=$ unconstrained: exponential (430)].

Bayes-factor analysis using the evolutionary models in Table 1 revealed that partitioning the data by codon position resulted in a large improvement in likelihood, whereas partitioning by gene resulted in a much smaller improvement. For example, the $2 \ln$ Bayes-factor result from comparing the one-partition and two-partition (by gene) strategy was 29.68 , but the result from comparing the two-partition and three-partition (by codon position) strategies was 772.22. The likelihood improvement going from three to six partitions (by gene and codon

Table 1

Evolutionary models for each partition of the RAG data as indicated by MrModeltest (Nylander, 2004)

\begin{tabular}{ll}
\hline Data partition & Model \\
\hline All data & GTR + I + G \\
RAG-1 & GTR + I + G \\
RAG-2 & GTR + I + G \\
1st codon position & GTR + I + G \\
2nd codon position & GTR + I + G \\
3rd codon position & GTR + G \\
RAG-1 1st codon position & GTR + I + G \\
RAG-1 2nd codon position & GTR + I + G \\
RAG-1 3rd codon position & GTR + G \\
RAG-2 1st codon position & GTR + I + G \\
RAG-2 2nd codon position & GTR + I + G \\
RAG-2 3rd codon position & GTR + G \\
\hline
\end{tabular}

position) was only 2.68 . Using the guideline that $2 \ln$ Bayes-factor values $>10$ indicated strong evidence against the alternative hypothesis (i.e. fewer partitions) we used three partitions for all Bayesian analyses of the combined nuclear gene dataset (Kass and Raftery, 1995; Brandley et al., 2005). Posterior probabilities for clades in the Bayesian analysis are shown on the ML tree (Fig. 2).

Length variation is relatively rare in protein coding genes compared with introns and ribosomal genes. The aligned matrix of RAG-1 and RAG-2 sequences revealed two instances of length variation. Both were inferred deletions in the RAG-1 gene and could be mapped unambiguously on the phylogeny. A 5-codon (15 bp) deletion compared with all other taxa united the thamnophilids and a 7-codon (21 bp) deletion compared with all other taxa united Myrmeciza pelzelni and Myrmeciza atrothorax. High posterior probability (100) and bootstrap support (100) for those clades indicated that single deletion events most parsimoniously explain the length variation.

\section{Large-scale phylogenetic relationships}

Broad agreement between parsimony- and the modelbased approaches, both in tree topology and in nodal support, simplifies discussion of phylogenetic relationships (Fig. 2). Disagreements occurred, but with few exceptions disputed nodes were not supported by high bootstrap proportions or posterior probabilities. In this section we present a general description of the phylogenetic results; in the Discussion that follows we present more detailed systematic comments within the context of previous work. Although our discussion of the phylogenetic results take a model-based tree as a guide (Fig. 2), the tree reflects the results of all three analyses, except as noted in the text. The values for branch support, shown in Fig. 2 and mentioned in the text, are reported as: (Bayesian posterior probability/ML bootstrap/MP bootstrap; all are expressed as percentages).

Support for the monophyly of the Furnariides was strong (100/100/99), but basal relationships within this clade were poorly resolved. Four lineages diverge at the base of the crown clade, but no analysis yielded strong support for any particular relationship among them. Two of the four lineages are small: one comprises the single genus Melanopareia (Melanopareiidae; represented by $M$. elegans and $M$. torquata), and the second is a sister pairing of Pittasoma rufopileatum and Conopophaga ardesiaca (Conopophagidae). The final two lineages are diverse and the primary topic of this paper: the Parvorder Thamnophilida (Thamnophilidae; Fig. 2a) and the Parvorder Furnariida (Fig. 2a, b). Support for the monophyly of each of these four clades was strong $(100 />90 / 90)$ in all analyses. Model-based analyses placed the Thamnophilidae as the basal taxon, 
but with poor support, whereas parsimony analysis placed Melanopareia + the Conopophagidae as sister to the thamnophilids, again with poor support.

Relationships within the Thamnophilidae were characterized by well-supported basal nodes, well-supported groups of genera in distal portions, and little support for intermediate clades. Four taxa (Terenura sharpei, Myrmornis torquata, Pygiptila stellaris, and Thamnistes anabatinus) were separated from all the other thamnophilid genera by a long internode. Terenura sharpei was the sister-group of the remainder of the family, and the other three taxa formed a clade sister to all other thamnophilids (Fig. 2a). This basal topology was found in all analyses, but support measures differed considerably. Model-based analyses recovered strong support (100 BP, $99 \mathrm{ML}$ ) for the node uniting all thamnophilids to the exclusion of the four basal taxa mentioned above. MP analysis also recovered this node, but with less than $50 \%$ bootstrap support.

The fourth basal lineage of the Furnariides was the Furnariida, which itself consisted of two lineages: the Grallarioidea and the Furnarioidea. The grallarioids included the Rhinocryptidae and the Grallariidae (Fig. 2a). This grouping appeared in all analyses, but branch support was only moderate $(93 / 75 / 68)$. The rhinocryptid clade included all traditional genera in the family other than Melanopareia, and within the rhinocryptids a clade consisting of the genera Myornis, Eugralla, and Scytalopus was sister to the rest. The grallariids consisted of the traditional formicariid genera Grallaria, Grallaricula, Hylopezus, and Myrmothera, and Grallaria was sister to the other genera.

The second sister-group (the Furnarioidea; Fig. 2b) comprised four well-supported lineages. At the base were the formicariid antpittas (Formicarius, Chamaeza), which were sister to all remaining furnariioids. Within the latter the Sclerurus-group (Geositta-Geobates/Sclerurus) was the sister-group of the woodcreepers (Dendrocolaptidae) plus the ovenbirds (Furnariidae).

\section{Discussion}

\section{Taxon sampling and assumptions of monophyly}

Although taxon sampling for this study was greatly expanded in comparison with earlier studies, several genera of the Thamnophilida (Biatas, Clytoctantes, Hylophylax, Rhopornis, Schistocichla, Skutchia, Stymphalornis, Xenornis) and Furnariida (Oreophylax, Merulaxis, Psilorhamphus, Siptornopsis, Clibanornis, Limnornis, Cichlocolaptes, Hylocryptus) were not included. Genetic material was not available for some of these taxa. For others, we could not obtain reliable sequence data and for a few we sequenced a sample that subsequently was shown not to be a member of the genus (e.g. "Hylophylax" poecilinotus). Most of these are taxa with small and geographically isolated distributions, hence their absence in tissue collections. Because they are not species-rich and have restricted ranges, omission of these few genera is not likely to alter substantially our interpretations of higher-level suboscine systematics, but this will only be tested in future family-level studies that are able to incorporate these taxa.

Another taxon sampling issue concerns our decision to sample a single individual for most genera. Because of this, much of our discussion implicitly assumes that genera are monophyletic. There is reason to believe that this is not a valid assumption. Samples from multiple species were included for some genera (eight of approximately 126 in the study), especially those suspected of non-monophyly. Several of these were found not to be monophyletic, and it is likely that several other genera will be revealed as non-monophyletic when densely sampled. The potential non-monophyly of genera also presents difficulties when comparing results across higher-level studies because species chosen to represent genera are seldom congruent across studies. Thus, the appearance of incongruent phylogenetic results may be the result of sparse taxon sampling and non-monophyly of genera. These situations will be discussed below as instances of potential incongruence but must be tested further with much denser taxon sampling.

\section{Basal relationships within the Furnariides}

Basal relationships within the Furnariides have not been clarified by our study, even with thorough taxon sampling and analysis of sequence data from relatively slowly evolving nuclear exons. Parsimony- and modelbased analyses give different basal topologies, but all conflicting nodes received low branch support. Until new data are produced, the base of the Furnariides radiation must be considered a polytomy containing four lineages (Fig. 2a). This lack of resolution mirrors the results of previous phylogenetic studies of basal relationships in the Furnariides (Irestedt et al., 2002; Chesser, 2004). Sequences from nuclear introns, nuclear exons, and mitochondrial genes have now been used to address basal relationships in this group and all have failed to provide any well-supported resolution. Thus, it is clear that lack of resolution is not due to reliance on regions that evolve too slowly or too quickly. It also seems that sparse taxon sampling is not the problem in these analyses, nor is it likely that sequences of unsampled taxa would break up long branches and provide greater resolution at the base of the group. Instead, future attempts at resolving the basal polytomy may find success in using more data per taxon. All studies thus far have been limited to no more than $4.5 \mathrm{~kb}$ of sequence data. 
FAMILY Thamnophilidae Swainson 1824

As already discussed, molecular sequence data from a number of workers have now demonstrated that there are at least four independent lineages of the Furnariides. One of the largest of these is the Thamnophilidae, the typical antbirds. Two recent studies, in particular, found support for the monophyly of thamnophilids using a variety of molecular markers (Irestedt et al., 2004a; Brumfield et al., 2007), and our results with the nuclear RAG-1 and RAG-2 genes also strongly support monophyly (100/100/100; Fig. 2a). In addition, we have discovered a 15-bp (5-codon) deletion in the RAG-1 gene that characterizes all thamnophilids sampled. This deletion is not found in any other suboscine group sampled, including the outgroups, and thus is clearly derived in thamnophilids.

A broad modern revision of the systematics and classification of the "typical antbirds" (Thamnophilidae) is lacking (Zimmer and Isler, 2003). Recent largescale molecular studies of the family now make it possible to build a much-improved framework for a phylogenetic classification for the group. Our results and those of Irestedt et al. (2004a) and Brumfield et al. (2007) have significantly improved understanding of generic groupings within thamnophilids. All three studies show broad congruence in generic clusters, although relationships within them are often different due to the use of markers that are evolving at quite different rates. Given this new knowledge, we propose formal names for some of these generic groups and use them to organize the ensuing discussion.

SUBF AMILY Myrmornithinae new rank (Myrmornithidae Sundevall 1872; type Myrmornis Hermann 1783)

Diagnosis. The most inclusive crown clade of species containing Myrmornis torquata and Thamnistes anabatinus but not Terenura sharpei, Microrhopias quixensis, Formicivora rufa, Frederickena viridis, or Pithys albifrons. No synapomorphies have been proposed, but the clade has strong molecular support.

Previous molecular studies (Irestedt et al., 2004a; Brumfield et al., 2007) have found that Terenura, Myrmornis, Pygiptila, and Thamnistes occur near the base of the tree. These four genera exhibit different body forms (two antshrikes, an antwren, and an antbird), are ecologically disparate, and, as a consequence, have been generally dispersed in taxonomic lists. Nevertheless, previous electrophoretic and DNA hybridization studies indicated that at least one of these genera (Pygiptila) was distantly related to other antshrikes (Hackett and Rosenberg, 1990) and to other antbirds generally (Sibley and Ahlquist, 1990). Irestedt et al. (2004a) united the four in their basal "Clade A" but it had weak support (BP 72). They found strong support for the clade
(Myrmornis (Pygiptila + Thamnistes)). Brumfield et al. (2007), in contrast, placed Terenura and then (Myrmornis (Pygiptila + Thamnistes)) as successive sister-groups to all other thamnophilids. Both nodes had strong support on their model-based tree, but these "basal" taxa became terminals in their MP analysis, suggesting a problem in rooting.

In all our analyses, Terenura and then the clade (Myrmornis (Pygiptila + Thamnistes)) were successive sister-groups to other thamnophilids (Fig. 2a), which agrees with the model-based results of Brumfield et al. (2007). Both nodes on our tree had moderate to strong support.

\section{SUBFAMILY Thamnophilinae}

TRIBE Microrhopiini, new taxon (type Microrhopias Sclater, 1862). Diagnosis. The most inclusive crown clade that contains Microrhopias quixensis, Myrmorchilus strigilatus, "Myrmeciza" atrothorax, and " $M$." pelzelni, but not Formicivora rufa, Thamnophilus caerulescens, Pyriglena leuconota, or Pithys albifrons. No synapomorphies have been proposed, but the clade has good molecular support.

In addition to the findings of Irestedt et al. (2004a) and Brumfield et al. (2007), this clade was supported by the RAG data (100/83/69) and was found to be the sistergroup of all the other Thamnophilinae (Fig. 2a). Irestedt et al. (2004a) recovered Microrhopias, Myrmorchilus, Neoctantes, and two stipple-throated species of Myrmotherula (both now placed in a new genus Epinecrophylla; Isler et al., 2006) as a basal clade within their Clade C. Similarly, Brumfield et al. (2007) found a clade composed of Microrhopias, Neoctantes, Epinecrophylla, Myrmorchilus, "Myrmeciza" pelzelni, and "Myrmeciza" atrothorax that was basal to other thamnophilids other than the Myrmornithinae. Because the type of Myrmeciza, M. longipes, goes elsewhere on the tree (see below), the nomenclatural status of pelzelni and atrothorax will need addressing once all species are sampled.

We did not sample Epinecrophylla, but considering the above evidence this genus is probably a member of the Microrhopini. Because Irestedt et al. (2004a) and Brumfield et al. (2007) strongly resolved a relationship between Neoctantes and Epinecrophylla, it came as a surprise that Neoctantes was not associated with the microrhopines on our tree but instead was placed as the sister-group of the remaining Thamnophilinae (with a BP of 100, but with ML and MP bootstrap values of only 60 and $<50$, respectively; Fig. $2 \mathrm{a}$ ). The slowly evolving RAG sequences may not be providing sufficient character data to resolve the short internodes in this part of the tree, whereas the faster evolving intron and mtDNA data used in the Irestedt et al. and Brumfield et al. studies may contain better phylogenetic signal. Regardless, this problem needs further study. 
TRIBE Formicivorini (Formicivoreae Bonaparte, 1854; type Formicivora Swainson 1824). Diagnosis. The most inclusive crown clade that contains Formicivora rufa and Myrmochanes hemileucus but not Thamnophilus caerulescens, Pyriglena leuconota, or Pithys albifrons. No synapomorphies have been proposed, but the clade is supported by molecular data.

We found moderately strong support (100/83/85) for a clade that includes Myrmochanes, Formicivora, and Myrmotherula axillaris. Previously, both Irestedt et al. (2004a) and Brumfield et al. (2007) also recovered this group with strong support, and they provided evidence that Myrmotherula is not monophyletic. The Formicivorini contain at least five species of Myrmotherula (including the type species, M. brachyura), but not all of these are monophyletic within the group (Irestedt et al., 2004a; Brumfield et al., 2007). Moreover, some " $M y r$ motherula" are in the Microrhopini (Irestedt et al., 2004a; see discussion of Epinecrophylla above). This situation has important implications for generic names, which can only be resolved with detailed species-level sampling; none of this should affect the higher-level group names.

The RAG data resolved the Formicivorini as the sistergroup of the remainder of the non-microrhopine Thamnophilinae, but branch support was lacking. This relationship, however, is corroborated with some support (BP 98, ML 61) by the dataset of Brumfield et al. (2007).

As noted in Tello et al. (2009), Bonaparte (1854) used family-group names ending in -eae as tribe-ranked taxa under subfamilies, and for reasons explained we take these as being valid family-group names. He proposed (Bonaparte, 1854, p. 132) the name Formicivoreae for Formicivora and six other genera that are not related on our tree. To our knowledge we are the first to use the spelling Formicivorini.

TRIBE Thamnophilini, new rank (type Thamnophilus Viellot 1816). Diagnosis. The most inclusive crown clade that contains Frederickena viridis, Thamnophilus caerulescens, Dysithamnus mentalis, and Dichrozona cincta but not Sclateria naevia, Myrmoborus leucophrys, or Pithys albifrons. No synapomorphies have been proposed, but the clade is well supported by molecular data.

The RAG data provide very strong support for the Thamnophilini (100/95/92; Fig. 2a). This group was also recovered by Irestedt et al. (2004a) with strong support (BP 95) and by Brumfield et al. (2007) with weak support. Relationships within our Thamnophilini (Fig. 2a) map relatively well to those of Clade B of Irestedt et al. (2004a), and both studies were unable to resolve the same basal nodes. This latter result could be explained if the group diversified over a relatively short period of time.

TRIBE Pyriglenini, new taxon (type Pyriglena $\mathrm{Ca}$ banis, 1847). Diagnosis. The most inclusive crown clade that contains "Myrmeciza" berlepschi, Sclateria naevia, and Myrmoborus leucophrys but not Pithys albifrons, Frederickena viridis, Thamnophilus caerulescens, or Thamnomanes ardesiacus. No morphological synapomorphies have been proposed, but the group is supported by molecular studies.

This clade appears on the RAG tree (Fig. 2a) but with weak support, although one subclade of four genera (Gymnocichla, Pyriglena, Myrmoborus, Percnostola) is very strongly supported and the core of its sister-group (Sclateria, Hypocnemoides) is moderately supported. The Pyriglenini are a well-supported clade (BP 100) within Clade $\mathrm{C}$ of Irestedt et al. (2004a) and on the tree of Brumfield et al. (2007); BP 100, ML 99), presumably because they used faster evolving markers than the RAG genes. The group can therefore be considered to be highly corroborated by molecular data.

Relationships within the group need more work, however. Percnostola is rendered non-monophyletic as in Brumfield et al. (2007), and the type species, P. rufifrons, clusters with Pyriglena and multiple species of "Myrmeciza" (Brumfield et al., 2007), whereas $P$. lophotes groups with Myrmoborus leucophrys (the type species of the genus). All four of these lineages form a reasonably well-supported clade $(96 / 81 / 63)$ that is sister to Gymnocichla. Interestingly, Myrmoborus and Pyriglena share a domed nest architecture nearly unique among thamnophilids (Zimmer and Isler, 2003), and $P$. rufifrons also builds a domed or enclosed nest (Willis, 1982; Tostain et al., 1992). The nest of P. lophotes has not been described but we predict that it will have a similar structure. The open-cup nesting Percnostola leucostigma, sometimes split off with $P$. schistacea and $P$. caurensis in the genus Schistocichla (Todd, 1927; Zimmer, 1931; see Isler et al., 2007 for a revision of species limits in the group), was previously found to be sister to Sclateria, which is in the second major lineage of the Pyriglenini. Thus, given that Percnostola is not monophyletic, current evidence suggests that an expanded Schistocichla will probably be a natural group. Several genera that we did not sample, including Schistocichla and Hylophylax, are also members of this group (Irestedt et al., 2004a; Brumfield et al., 2007).

The type of Myrmeciza, M. longipes, was not sampled in this study but probably occurs in a clade that includes $M$. berlepschi and M. exsul (R. T. Brumfield, unpublished data). Irestedt et al. (2004a) grouped M. griseiceps with $M$. berlepschi and their sister-group was a clade consisting of ("M." loricata (Hypocnemoides + Hylophylax naevia)). Brumfield also included " $M$. ." fortis, "M." immaculata, "M." goeldii, "M." melanoceps, and "M." exsul in our Pyriglenini. There appear to be at least three, perhaps four, independent lineages of "Myrmeciza" in this tribe but denser species-level sampling will be required to clarify this.

TRIBE Pithyini, new rank (type Pithys Vieillot 1818). Diagnosis. The most inclusive crown clade that contains 
Cercomacra tyrannina, Pithys albifrons, and Gymnopithys rufigula but not Pyriglena leuconota, Sclateria naevia, Frederickena viridis, or Formicivora rufa. No morphological synapomorphies have been proposed for this group, but it is strongly supported by molecular data.

Ridgway (1911, p. 16) created the family-group name Pithyeae in a key of the Thamnophilidae. His intention was to cluster together seven genera (Pithys, Hylophylax, Sclateria, Anoplops (= Gymnopithys), Rhegmatorhina, Phlegopsis, and Phaenostictus) within his Formicariinae. This group was not formally ranked; thus we do that here at a tribal level, which is consistent with Ridgway's treatment. To our knowledge Bock (1994, p. 148) was the first to use the family-rank name "Pithyidae", based on Pithyeae Ridgway, as a synonym under Formicariidae.

The RAG data strongly support two small clades: (i) Cercomacra (Drymophila + Hypocnemis) (100/100/99), and(ii)((Pithys + Phaenostictus)(Willisornis (Phlegopsis (Gymnopithys + Rhegmatorhina)))) (100/99/94). These two clades are united on the RAG tree but with no support. These same two clades were recovered by Irestedt et al. (2004a) with strong support (BP 100) and by Brumfield et al. (2007), also with strong support (BP 100, ML 72). Hence the Pyriglenini has strong molecular support.

The one species of "Hylophylax" included in the RAG study, "H." [= Willisornis $]$ poecilinotus, was demonstrated here and by Brumfield et al. (2007) to be closely related to the clade of army-ant following birds that includes Pithys, Phaenostictus, Phlegopsis, Gymnopithys, and Rhegmatorhina (and presumably Skutchia, although this genus was not sampled), and to be only distantly related to the other three species in the genus Hylophylax, including the type species $H$. naevioides, which are related to Hypocnemoides (Brumfield et al., 2007). "Hylophylax" poecilinotus differs considerably from the other Hylophylax species and instead shares certain behavioural features (e.g. nesting) with the genera that follow army ants (Zimmer and Isler, 2003). The genus name Dichropogon was recently resurrected for this distinctive species (Remsen et al., 2007) but was subsequently shown to be a junior homonym. Agne and Pacheco (2007) proposed the new genus name Willisornis, and we follow that here and in Fig. 2a. In addition, at least one species of "Myrmeciza", which we did not sample, "M." hemimelaena, is included in this group and is probably sister to Cercomacra (Brumfield et al., 2007; see also Irestedt et al., 2004a).

\section{Melanopareia and Conopophaga/Pittasoma}

Melanopareia was traditionally placed in the Rhinocryptidae, Conopophaga in its own monogeneric family Conopophagidae, and Pittasoma in the Formicariidae sensu lato. Our data, by contrast, indicated that Melanopareia constitutes one of the four basal lineages of the furnariine suboscines, and that Conopophaga and Pitta- soma are sister genera that constitute a second major basal lineage. These findings place into context the results of several other studies in which these were found to form distinctive clades. Irestedt et al. (2002), for instance, found Melanopareia to be an isolated lineage, and sister to all other furnariines (Fig. 1a), although MP bootstrap support (51\%) for this result was low. Chesser (2004) also found Melanopareia to form a distinct basal lineage, one whose relationships to other groups were unresolved (Fig. 1b). In Chesser's study, Conopophaga was also found to be a distinct lineage (nuclear decay index of 25, by far the highest value in his study); his tree suggested conopophagids were sister to the Thamnophilidae but branch support was very low. Pittasoma was not sequenced in either study, but using more detailed sampling of ground antbirds Rice (2005a, b) found that Pittasoma was the sister-genus to Conopoph$a g a$, a finding we corroborate here.

\section{PARVORDER Furnariida}

As discussed above, most of the taxa formerly included in the ground antbird family Formicariidae are now partitioned off into the family Thamnophilidae. The remainder are known to consist of two distinct lineages, one including the ant-thrushes Formicarius and Chamaeza (Formicariidae sensu stricto) and the other consisting of the ant-pitta genera Grallaria, Grallaricula, Myrmothera, and Hylopezus (Grallariidae). Previous studies indicated that these two families are not sistergroups. Thus, both Irestedt et al. (2002) and Chesser (2004) found the pattern: (((Formicariidae + Furnariidae sensu lato) Rhinocryptidae) Grallariidae). More recently, Rice (2005a, b) suggested that the Formicariidae and Rhinocryptidae were sister-taxa and that the Grallariidae were outside of this grouping (his studies did not include any furnariids, so his results are consistent with the studies just mentioned). Our results propose novel relationships among the groups included in the Furnariida, specifically that the Grallariidae are sister to the Rhinocryptidae and that the Formicariidae are sister to the Furnariidae. Support for these relationships was moderate for Grallariidae + Rhinocryptidae (93/75/68; Fig. 2a) to strong for the Furnarioidea (100/84/77; Fig. 2b).

\section{SUPERFAMILY Grallarioidea, new rank (type Grallaria Vieillot 1816)}

Diagnosis. The most inclusive crown clade that includes Grallaria eludens and Rhinocrypta lanceolata but not Melanopareia elegans, Conopophaga ardesiaca, Thamnophilus caerulescens, Formicarius colma, or Furnarius rufus. There are no known morphological synapomorphies, but the group is well supported by molecular characters. 


\section{FAMILIES Grallariidae and Rhinocryptidae}

Previous in-depth molecular work on the Grallariidae (Rice, 2005a) indicated that the genus Grallaria is monophyletic and is sister to a clade consisting of ((Hylopezus + Myrmothera) Grallaricula). Our results (Fig. 2a), based on relatively limited taxon sampling, are congruent with this hypothesis. Within the genus Grallaria, molecular data (Rice, 2005a) also supported the subgeneric divisions proposed by Lowery and O'Neill (1969) based on morphological characters, but our results, although tempered by incomplete sampling within the genus, are inconsistent with that conclusion. We sampled three species of Grallaria, two (andicola and ruficapilla) from the subgenus Hypsibemon and one (eludens) from the subgenus Thamnocharis, and recovered ruficapilla and eludens as sister-taxa. This result received strong support $(100 / 100 / 97)$, but more extensive taxon sampling is undoubtedly needed to determine the validity and generality of this discrepancy. We note, however, that Krabbe and Schulenberg (2003a) reference unpublished molecular work on 18 species of Grallaria that also found subgenera of this genus to be paraphyletic.

Relatively little prior work has been conducted on relationships of the diverse taxa within the family Rhinocryptidae, and previous molecular investigations (Chesser, 1999, 2004; Irestedt et al., 2002) included only limited sampling of the family. We sequenced representatives of most genera within the family, although we were unable to sample Psilorhamphus and Merulaxis. Our results indicated that the family consists of two well-supported clades that can be formally recognized.

SUBFAMILY Scytalopodinae, new rank (Scytalopodidae (J. Müller), type Scytalopus Gould 1836). Diagnosis. The most inclusive crown clade that contains Myornis senilis, Eugralla paradoxa, and Scytalopus magellanicus but not Pteroptochos castaneus, Rhinocrypta lanceolata, or Grallaria ruficapilla.

Within this group, Eugralla and Scytalopus, which differ in a number of plumage and behavioural features (Krabbe and Schulenberg, 2003b), are sister-genera (Fig. 2a).

SUBFAMILY Rhinocryptinae, new rank (Rhinocryptidae Wetmore, 1930, type Rhinocrypta Gray 1840). Diagnosis. The most inclusive crown clade that contains Pteroptochos castaneus, Liosceles thoracicus, and Rhinocrypta lanceolata but not Myornis senilis, Scytalopus magellanicus, or Grallaria ruficapilla.

Within this clade, the southern Andean genera Pteroptochos and Scelorchilus are sister to a lineage containing the remaining genera. Two genera of the arid lowlands of southern South America, Teledromas and Rhinocrypta, were sister-groups within the latter clade, with Acropternis from the northern Andes sister to them and Liosceles sister to all three. Support for most of these clades was strong (Fig. 2a). Behavioural and morphological similarities have been noted between Eugralla and Merulaxis, and it is possible that the unsampled genus Merulaxis forms part of the MyornisEugralla-Scytalopus clade (Krabbe and Schulenberg, 2003b). It has been speculated that the true affinities of Psilorhamphus, in contrast, lie outside the Rhinocryptidae (e.g. Ridgely and Tudor, 1994). Pteroptochos Kittlitz 1830 is the oldest generic name in this clade, but because the name Rhinocryptidae (based on Rhinocrypta Gray 1840) has been used almost universally, at least since Wetmore (1930) and Peters (1951), it should have preference under the International Code of Zoological Nomenclature (ICZN, 1999).

\section{SUPERFAMILY Furnarioidea}

We recognize four family-level taxa within the superfamily Furnarioidea (Fig. 2b): (Formicariidae (Scleruridae (Dendrocolaptidae + Furnariidae $))$ ).

\section{FAMILY Formicariidae}

The family includes only Formicarius and Chamaeza, which are highly supported as sister-taxa $(100 / 100 / 100)$ and the sister-group of all other furnarioids (see comments above under Furnariida).

FAMILY Scleruridae (Sclerurina Swainson, 1927; type Sclerurus Swainson, 1927)

Diagnosis. The most inclusive crown clade that contains Sclerurus mexicanus, Geositta poeciloptera, and Geositta isabellina but not Dendrocolaptes certhia or Furnarius rufus.

Our data corroborated furnariid paraphyly as reported in recent studies (Irestedt et al., 2002; Chesser, 2004). Three furnariid genera, Sclerurus, Geositta, as well as Geobates, which is nested within Geositta (Cheviron et al., 2005) and hence is included in Geositta here, were strongly supported as being monophyletic (100/93/86; Fig. 2b) and as the sister to the dendrocolaptids + the remaining furnariids $(100 / 100 / 100)$. The family-group name Scleruridae Swainson is available for these taxa. Swainson (1827), p. 356) proposed a new subfamily "Sclerurina" for a new genus Sclerurus. He provided a diagnosis for the latter but did not specify a type species, which was later provided by Cabanis (1847, p. 231). Sclater (1862, p. 149) first used the name Sclerurinae.

\section{FAMILY Dendrocolaptidae}

The RAG data identify two major clades of woodcreepers, each with strong support, and these two 
groups were also previous recovered by Irestedt et al. (2004b). We therefore designate these groups formally.

SUBFAMILY Sittasominae, new rank (Sittasomae Ridgway 1911, type Sittasomus Swainson, 1927). Diagnosis. The most inclusive crown clade that contains Sittasomus griseicapillus, Deconychura longicauda, and Dendrocincla fuliginosa but not Glyphorynchus spirurus, Xiphorhynchus picus, or Dendrocolaptes certhia. The clade also appears to be diagnosed by molecular synapomorphies, a 34-bp and a 1-bp deletion in the G3PDH intron 11 (Irestedt et al., 2006).

In a key to the family Dendrocolaptidae, Ridgway (1911, p. 227) placed Sittasomus by itself in a group Sittasomae within his Glyphorhynchinae (which also included Dendrocincla and Deconychura). The name Sittasomae was unranked. Bock (1994, p. 147) transcribed that name as "Sittasomidae" in his synonomy of Dendrocolaptidae, thus using the family name for the first time.

SUBFAMILY Dendrocolaptinae (type Dendrocolaptes Hermann 1804). Diagnosis. The most inclusive crown clade that contains Glyphorynchus spirurus, Xiphorhynchus picus, and Dendrocolaptes certhia but not Sittasomus griseicapillus or Dendrocincla fuliginosa. The clade also appears to be diagnosed by a molecular synapomorphy, a 3-bp insertion in the G3PDH intron 11 (Irestedt et al., 2006).

Two other important relationships reported in recent studies, which affect not only taxonomic decisions but also the interpretation of evolutionary trends within the dendrocolaptids, were not supported by our data. Feduccia (1973) used morphological and protein data to divide the woodcreepers into "intermediate" (ovenbird-like) and "strong-billed" groups. The monotypic genus Glyphorynchus was included with the "intermediates" but closely approached the "strong-billed"-group in several characters. Recent molecular studies (Irestedt et al., 2004b, 2006; Fjeldså et al., 2005) recovered Feduccia's two groups, but with one important exception. Rather than being with the other "intermediate" taxa or close to the "strong-billed" ones, Glyphorynchus spirurus was reconstructed as sister to all other woodcreepers. The interpretation of this placement was that convergent evolution of skull morphologies had occurred in clades (Glyphorynchus and the "strong-billed" genera) that tended towards woodpecker-like behaviours (Irestedt et al., 2004b). Our data do not support such a conclusion (Fig. 2b). Strong bootstrap and posterior probabilities support a phylogenetic branching pattern that is consistent with Feduccia's hypothesis, which he expressed as a Prim network. On the latter, Feduccia placed three genera (Dendrocincla, Deconychura, and Sittasomus) in a position "intermediate" between various furnariid taxa and Glyphorynchus, the latter of which was followed by the "strong-billed" genera. This maps to our phylogenetic results.

Irestedt et al. (2004b, 2006) and Fjeldså et al. (2005) analysed similar data sets; all used cytochrome $b$ and myoglobin intron 2, and Fjeldså et al. (2005) and Irestedt et al. (2006) added G3PDH intron 11. Each successive study included additional samples, but a large number of sequences were shared among the studies. Thus, the three phylogenies are not independent phylogenetic hypotheses. Importantly, only one of the three genes they analysed (cytochrome b) recovered Glyphorynchus in a basal position among the dendrocolaptids. Both of the nuclear introns placed Glyphorynchus within the woodcreeper radiation. In their combined analyses Glyphorynchus was basal, with (Fjeldså et al., 2005) or without (Irestedt et al., 2004b) significant support. The intron data, however, yielded independent evidence that the cytochrome $b$ topology may be misleading. Fjeldså et al. (2005) listed indels that are incongruent with their phylogeny. A single 3-bp insertion relative to all other taxa unites Glyphorynchus with the "strong-billed"-group. Of five gene regions analysed thus far, only cytochrome $b$ supports a basal position for Glyphorynchus in the Dendrocolaptidae. Three gene regions (RAG-1, RAG-2, and G3PDH) and one indel place Glyphorynchus sister to the "strongbilled" clade which, in turn, supports a hypothesis of morphological change from more ovenbird-like to more woodpecker-like within the family, rather than two independent origins of woodpecker-like morphology.

\section{FAMILY Furnariidae}

The nuclear RAG-1 and RAG-2 dataset provides the largest taxon sampling to date for the Furnariidae, and thus has resulted in many new insights into their interrelationships. In fact, little previous work has been done on intergeneric relationships (see discussion of Remsen, 2003), and the only study with moderate taxon sampling is that of Irestedt et al. (2006), who examined 37 genera (43 terminals) using two nuclear introns (myoglobin intron 2, G3PDH intron 11) and the cytochrome $b$ gene. Our phylogenetic hypothesis (Fig. 2b) includes 50 genera and 54 terminals. Although these two studies have a number of generic sister-pairs in common (here and below we refer to their Bayesian analysis of the combined data; Irestedt et al., 2006; Fig. 2), considerable conflict exists as well. In general, data from the slower RAG genes better resolve the deeper and intermediate nodes and with somewhat higher support than do the Irestedt et al. data.

Because relationships within furnariids have been uncertain, classification schemes have been based primarily on phenetic assessments. Although our data do not provide complete resolution, they now allow us to delimit a series of natural groupings, generally with strong character support. We therefore propose some 
new formal names and set new limits to previously described ones that should help provide a systematic framework for future research on the family (see below).

Xenops and Berlepschia are, respectively, the two most basal and successive taxa on our tree (Fig. 2b). They are followed by the Pygarrhichini (100/100/97), which is resolved as the sister-group of our "Furnariinae" + Synallaxinae with moderately strong support $(99 / 70 / 55)$, as is the sister-group relationship of the latter two subfamilies $(100,81,72)$.

The placement of Xenops as the sister-group of the remainder of the Furnariidae and the monophyly of the Pygarrhichini highlight differences from previous work. Fjeldså et al. (2005) and some analyses of Irestedt et al. (2006) found Xenops (represented by X. minutus and $X$. rutilans) to be sister to, or imbedded in, the Dendrocolaptidae rather than occupying its more typical placement among the furnariids. Together with the inferred basal position of Glyphorynchus among the dendrocolaptids, Fjeldså et al. (2005) used the placement of Xenops to develop a narrative about the evolution of feeding behaviour and morphology. We did not recover Xenops as sister to the Dendrocolaptidae, and the two species we sampled (X. minutus and " $X$." milleri) were not themselves sister-taxa. Microxenops milleri $(=X$. milleri $)$ was part of the well-supported Pygarrhichini that also included three monotypic genera (Chilia, Eremobius, and Pygarrhichas), and X. minutus was reconstructed as the sister-group of the remaining furnariids; neither species of Xenops was sister to the dendrocolaptids. Bill shape and some plumage characters of Microxenops milleri are somewhat aberrant compared with the other three species in the genus (Remsen, 2003); neither Fjeldså et al. (2005) nor Irestedt et al. (2006) sampled milleri.

As was the case with Glyphorynchus, individual gene trees in Fjeldså et al. (2005) and Irestedt et al. (2006) differ in the placement of Xenops; only G3PDH places it sister to the Dendrocolaptidae, a result that has low support. In fact, the only gene region (cytochrome $b$ ) that identifies a sister-taxon for Xenops with high posterior probability places it sister to the ovenbirds, the same relationship supported by RAG-1 and RAG-2. As demonstrated by Fjeldså et al. (2005), the relationships of this genus have important implications for interpreting evolution in woodcreepers and ovenbirds, but these implications now need to be re-evaluated. Another subject for future inquiry is the nature of the incongruent phylogenetic signal contained in different genes in comparisons of Glyphorynchus and Xenops.

SUBFAMILY Pygarrhichinae (Wolters, 1977; type Pygarrhichas Burmeister, 1837). Diagnosis. The most inclusive crown clade that contains Pygarrhichas albogularis, Chilia melanura, and Microxenops milleri but not Furnarius rufus, Philydor pyrrhodes, Synallaxis albes- cens, Berlepschia rikeri, or Xenops minutus. No morphological synapomorphies are known, but the clade has strong molecular support.

The nomenclature of the type-genus has been complex and confusing since the time it was coined. Burmeister (1837, p. 769) introduced a new genus "Pygarrhichas Licht." presumably in reference to a name that may have been proposed by Martin Lichtenstein in a manuscript that was never formally published. The name Pygarrhichas Burmeister is derived from the Greek "puge" (rump) and the masculine " $\alpha \rho \rho \imath \chi o \sigma "$, or "arrichos" (wicker basket; from ancient Greek; see http://www.perseus.tufts.edu/cgi-bin/ptext?doc $=$ Perseus\%3Atext\%3A1999.04.0057\%3Aentry\%3D\%23 15530). Burmeister's name was Latinized with " $\operatorname{arr}(\mathrm{hi})-$ ch(as), which is a nominative singular, feminine ending. Soon thereafter, however, some ornithologists began using "Pygarrhichus" with a Latinized -us ending. Thus, Cabanis (1847, p. 232) stated "Pygarrhichus Licht. 1837" (translated from German): "Pygarrhichus has priority before the names suggested by Gould [1841, Dendrodromus] and Gray [1842, Dromodendron], because the type [assuming he meant 'Gattung' to refer to the type species rather than the genus] already became [has been] characterized in Burmeister's Handbuch der Naturgeschicte 1837. p. 769." The confusion did not end there, as just 3 years later Bonaparte $(1850,209)$ referred to "Pygarrhicus, Licht. 1837", thereby introducing yet another spelling by dropping the Greek letter $\chi$ in the name (as did Hartlaub, 1853; Bonaparte, 1854; Sclater, 1890; Cory and Hellmayr, 1925). A few others, such as Peters (1951) and Wolters (1977), maintained Burmeister's original Pygarrhichas. Wolters (1977, no. 3, p. 199) erected the family-group name Pygarrhichinae. Without explanation or justification, Bock (1994, p. 148) listed this name as "Pygarrhichadinae" as a synonym of the Philydorinae. If this was not a typographical error, then he presumably altered the -as ending to the nominative (fem.) plural -ades, then dropped the -es and added -inae. Because Bock's emendation was not justified, and is probably incorrect, our subfamily-rank name follows Wolters (1977).

SUBFAMILY "Furnariinae". Our tree recovers two major subdivisions within the Furnariidae. One is the Synallaxinae, and it has strong support (100/82/68). The second contains two well-supported clades - here called the Furnariini and Philydorini. They are resolved as sister-groups but there is no branch support for this relationship. We tentatively call this clade the "Furnariinae" and place the name in quotes here and on Fig. $2 b$ to signify its very tentative status. Additional data will be needed to clarify the boundaries of this subfamily.

TRIBE Furnariini, new rank (Furnarinae Gray 1840 [Furnariinae Cabanis, 1847], type Furnarius Vieillot 1816). Diagnosis. The most inclusive crown clade that 
contains Furnarius rufus, Upucerthia dumetaria, and Premnornis guttuligera but not Philydor pyrrhodes or Synallaxis albescens.

There are two clades within our Furnariini that are generally recovered by other investigators but the two are not always sister-taxa in those studies. On our tree they have very high branch support (100/96/82; Fig. 2b). The first clade (Furnariini-1) includes Furnarius, Phleocryptes, Lochmias, Upucerthia sensu stricto, Cinclodes, as well as probably Limnornis, which Gonzalez and Wink (2008) found to cluster with Phleocryptes and Lochmias. The second clade (Furnariini-2) includes Pseudocolaptes and Tarphonomus (formerly part of Upucerthia; Chesser and Brumfield, 2007). The two groups are united also on the combined Bayesian tree of Irestedt et al. (2006) but not with strong support (BP 90), as well as on the tree of Olson et al. (2005) but again with poor support. In contrast, the work of Chesser et al. (2007) has Furnariini-1 clustering with the phylydorine taxa, with Furnariini-2 as their sister. Also, Fjeldså et al. (2007) found that Furnariini-1 clustered with synallaxine genera, and that Furnariini-2 was their sister-group, with philydorines being far distant. These conflicting results call for additional data and analysis.

TRIBE Philydorini. Diagnosis. The most inclusive crown clade that contains Automolus infuscatus, Philydor pyrrhodes, and Syndactyla rufosuperciliata but not Furnarius rufus, Pygarrhichas albogularis, or Synallaxis albescens.

On the RAG-1 and RAG-2 tree this clade is extremely well supported (100/100/100; Fig. 2b). Other studies also find this clade using a wide variety of markers (e.g. Olson et al., 2005; Irestedt et al., 2006; Chesser et al., 2007; Fjeldså et al., 2007).

Intergeneric relationships are incompletely resolved by the RAG data. One subclade is strongly supported (100/87/75) and includes the generic groupings: (i) ((Simoxenops + Syndactyla) Anabacerthia), (ii) (Philydor + Heliobletus) Anabazenops, and (iii) Megaxenops. The second subclade includes: (( $($ Automolus + Hyloctistes) Thripadectes) Ancistrops). We did not include Hylocryptus but others have found that it is sister to Automolus (Irestedt et al., 2006; Fjeldså et al., 2007, both with overlapping data).

SUBFAMILY Synallaxinae. Within the furnariids one large clade of 26 genera, which we demarcate as the Synallaxinae (Fig. 2b), was strongly monophyletic $(100 / 82 / 68)$. Along its "spine" there is a series of nodes, most of which are also strongly supported by RAG sequences. At the base of the synallaxine tree is Margarornis + Premnoplex (but not Premnornis or Roraimia; Rudge and Raikow, 1992). Although these two genera have been associated on other trees (e.g. Irestedt et al., 2006) their deep relationships to other genera have been uncertain, probably because mito- chondrial and nuclear intron markers are not giving a sufficiently clear phylogenetic signal for these taxa. The next clade off the tree is Aphrastura, followed by Leptasthenura + Sylviorthorhynchus, a relationship also found by Gonzalez and Wink (2008). All of these nodes are strongly supported by our data. These are followed by a large clade of 21 genera $(100 / 85 / 76)$ that represents the core of the Synallaxinae. Although basal relationships remain uncertain, we recognize two well-supported clusters of genera at the rank of tribe (below).

The name of this family-group taxon deserves comment. Bock (1994, p. 195) listed this family-group name as, quoting, "Synallaxeinae de Selys-Longchamps, 1839 (1836) which takes precedence from 1836 and which is the valid name for this family-level taxon" [his specifying 1836 is presumably because Anabatinae Sundevall 1836 is a synonym of "Synallaxeinae" as Anabates is a synonym of Synallaxis]. The names "Synallaxeidae" (Bock, 1994, p. 147) and "Synallaxeinae" (Bock, 1994, pp. 194-195), unfortunately, are new names created by Bock when he transcribed de Selys-Longchamps' (1839, p. 13) name "Synallaxidées". De Selys-Longchamps (1839, p. 12) specifically referred to his groups as families (giving them all the suffix "idées" and he listed their principal genera; under the code (Article 11) these are valid family-group names but the suffix must be changed. The name of the family-group is based on Synallaxis Vieillot 1818 and takes the date when it was first proposed (1839).

TRIBE Synallaxini. Diagnosis. The most inclusive crown clade of species that contains Synallaxis albescens and Certhiaxis cinnamomeus but not Thripophaga fusciceps.

Our diagnosis is minimal because there is uncertainty about where some unresolved and closely related lineages-Spartonoica + Pseudoseisura, Phacellodomus, Anumbius + Coryphistera, or Hellmayrea, and others - might eventually be placed (Fig. 2b).

At present the Synallaxini (100/100/99) includes $(($ Synallaxis + Gyalophylax $)$ Poecilurus $)+($ Certhiax is + Schoeniophylax). One or more other lineages will probably be sisters to these genera, in which case the tribe may be expanded.

TRIBE Thripophagini, new taxon (type Thripophaga Cabanis, 1847). Diagnosis. The most inclusive crown clade that contains Acrobatornis fonsecai, Xenerpestes singularis, and Thripophaga fusciceps but not Synallaxis albescens.

This tribe (100/100/99) now includes eight genera in essentially a trichotomy (Fig. 2b): (i) Acrobatornis, (ii) Metopothrix + Xenerpestes, and (iii) (Limnoctites + Cranioleuca) + (Siptornis (Thripophaga + Roraimia) $)$. Some other genera are ambiguously related to the Thripophagini and may possibly be shown to be closer to various synallaxine lineages. On our tree Asthenes is non-monophyletic and Schizoeaca is imbedded within it. 
Together they form a well-supported lineage $(100 / 88 / 77)$, but their relationships to other taxa are unclear, as is that of Hellmayrea, which is closer to thripophagines on the basis of RAG data (yet with no support) but could be synallaxine instead (e.g. Irestedt et al., 2006; Gonzalez and Wink, 2008), although the evidence for that placement is also weak at present.

\section{Toward a phylogenetic classification of the Furnariides}

The dense taxon-sampling of the present study provides a basis for developing more fully a phylogenetic classification of both the Thamnophilida and the Furnariida. In parallel with our approach to classification in our companion paper on the Tyrannides (Tello et al., 2009), we adopt the rank of Parvorder for both the Thamnophilida and the Furnariida following Sibley et al. (1988) and Sibley and Monroe (1990). Names for subgroups within these two large clades have been influenced by the results of Irestedt et al. (2002) and Chesser (2004), but when necessary we have departed from these workers as a result of our denser taxonsampling and different phylogenetic findings. Moreover, we employ the same classification conventions of Tello et al. (2009). Accordingly, we represent the topology of Fig. 2 using a phyletic sequencing convention (Nelson, 1972, 1973; Cracraft, 1974; Wiley, 1979, 1981; see Tello et al., 2009; for more details of our approach). Thus, a taxon at a given level of subordination (indentation), regardless of its Linnean rank, is the sister-taxon of all those below it at the same level of subordination; for example, Parvorder Thamnophilida is the sister-taxon of (Melanopareiidae (Conopophagidae + Parvorder Furnariida)). In cases of polytomies where phyletic sequencing must be abandoned, we identify each taxon of the polytomy with an asterisk $(*)$; for the purposes of representing the tree faithfully in this classification, we treat even poorly supported nodes as being resolved. These conventions facilitate the maintenance of named taxa that will be largely familiar to working systematists and other ornithologists and at the same time allow for the incorporation of new, supported concepts of group membership (see Tello et al., 2009).

To place our classification in context, the higher-taxa of the Order Passeriformes can be arranged as follows:

\footnotetext{
Order Passeriformes

Suborder Acanthisitti (New Zealand wrens)

Suborder Passeri (oscine passerines)

Suborder Tyranni (suboscine passerines) Infraorder Eurylaimides (Old World suboscines) Infraorder Tyrannides (New World suboscines) Infraorder Furnariides

Parvorder Thamnophilida, sedis mutabilis Family Thamnophilidae

Family Conopophagidae, sedis mutabilis Family Melanopareiidae, sedis mutabilis
}

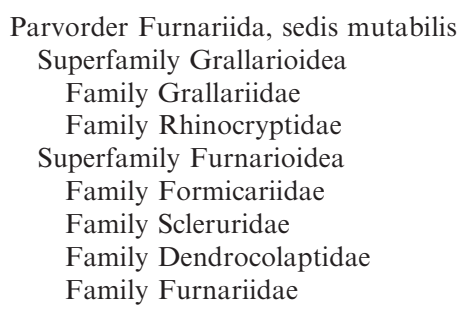

We propose that the Infraorder Furnariides be classified as follows:

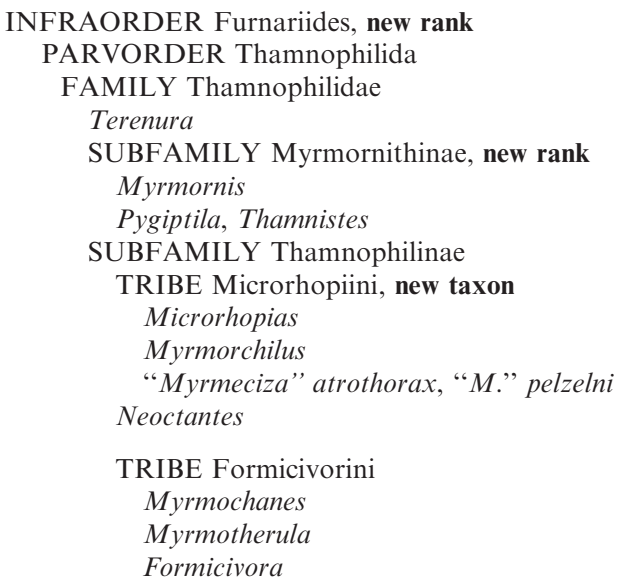

TRIBE Pyriglenini, new taxon

Sclateria group: "Myrmeciza" berlepschi

Sclateria, Hypocnemoides

Pyriglena group: Gymnocichla

Pyriglena, Percnostola rufifrons

Myrmoborus, Percnostola lophotes

TRIBE Pithyini, new rank

Drymophila group: Cercomacra

Pithys group: $\quad$ Prymophila, Hypocnem

Willisornis poecilinotus Phlegopsis Gymnopithys, Rhegmatorhina FAMILY Melanopareiidae
Melanopareia

FAMILY Conopophagidae Conopophaga, Pittasoma

PARVORDER Furnariida

SUPERFAMILY Grallarioidea, new rank FAMILY Grallariidae

Grallaria

Grallaricula

Hylopezus, Myrmothera 


\section{FAMILY Rhinocryptidae \\ SUBFAMILY Scytalopodinae, new rank Myornis \\ Eugralla, Scytalopus \\ SUBFAMILY Rhinocryptinae, new rank \\ Scelorchilus, Pteroptochos \\ Liosceles \\ Acropternis \\ Rhinocrypta, Teledromas}

SUPERFAMILY Furnarioidea

FAMILY Formicariidae

Formicarius, Chamaeza

FAMILY Scleruridae

Sclerurus

Geositta (inc. Geobates)

FAMILY Dendrocolaptidae

SUBFAMILY Sittasominae, new rank

Dendrocincla

Deconychura, Sittasomus

SUBFAMILY Dendrocolaptinae

Glyphorynchus

Xiphorhynchus group: Xiphorhynchus Campylorhamphus Drymornis, Lepidocolaptes

Dendrocolaptes group: Nasica, Dendrexetastes Dendrocolaptes Xiphocolaptes, Hylexetastes

FAMILY Furnariidae

Xenops

Berlepschia

SUBFAMILY Pygarrhichinae

Pygarrhichas

Microxenops

Eremobius, Chilia

SUBFAMILY "Furnariinae"

TRIBE Furnariini, new rank

Pseudocolaptes group: Pseudocolaptes

Tarphonomus, Premnornis

Furnarius group: Upucerthia, Cinclodes

Furnarius

Phleocryptes, Lochmias

TRIBE Philydorini

Automolus group: Ancistrops

Thripadectes

Hyloctistes, Automolus

Philydor group: *Megaxenops

*Anabazenops (Philydor, Heliobletus)

* Anabacerthia (Syndactyla, Simoxenops)

SUBFAMILY Synallaxinae

Margarornis group: Premnoplex, Margarornis

Aphrastura

Sylviorthorhynchus group: Leptasthemura, Sylviorthorhynchus

* Spartonoica group: Spartonoica, Pseudoseisura

*UNNAMED HIGHER TAXON: Synallaxini and allies

*Phacellodomus

*Anumbius, Coryphistera

*TRIBE Synallaxini

Schoeniophylax, Certhiaxis Poecilurus (Gyalophylax, Synallaxis)

*UNNAMED HIGHER TAXON: Thripophagini and allies

*Hellmayrea

*Asthenes group: “Asthenes," Schizoeaca

*TRIBE Thripophagini, new taxon

Acrobatornis

Metopothrix, Xenerpestes
Limnoctites, Cranioleuca

Siptornis

Thripophaga, Roraimia

\section{Acknowledgements}

We thank the following institutions for generous tissue loans: Field Museum of Natural History, US National Museum of Natural History, and the Zoological Museum at the University of Copenhagen. We also thank all of the field collectors whose efforts made this project possible. Richard C. Banks (Smithsonian Institution) provided invaluable comments and advice on nomenclatural issues for which we are deeply grateful. This research was supported by grants from the National Science Foundation ("Assembling the Tree of Life" EAR-0228693, and NSF DEB-0543562). These studies were also supported by the L. J. and L. C. Sanford Funds, and the Lewis B. and Dorothy Cullman Program for Molecular Systematic Studies, a joint initiative of the New York Botanical Gardens and the American Museum of Natural History, as well as by the Sackler Institute of Comparative Genomics, AMNH.

Any use of trade, product, or firm names is for descriptive purposes only and does not imply endorsement by the US Government.

\section{References}

Agne, C.E.Q., Pacheco, J.F., 2007. A homonymy in Thamnophilidae: a new name for Dichropogon Chubb. Revista Brasileira de Ornitologia 15, 484-485.

Ames, P.L., 1971. The morphology of the syrinx in passerine birds. Bull. Peabody Mus. Nat. Hist. 37, 1-194.

Barker, F.K., Lutzoni, F.M., 2002. The utility of the incongruence length difference test. Syst. Biol. 51, 625-637.

Barker, F.K., Barrowclough, G.F., Groth, J.G., 2002. A phylogenetic hypothesis for passerine birds: taxonomic and biogeographic implications of an analysis of nuclear DNA sequence data. Proc. R. Soc. Lond. B 269, 295-308.

Barker, F.K., Cibois, A., Schikler, P., Feinstein, J., Cracraft, J., 2004. Phylogeny and diversification of the largest avian radiation. Proc. Natl Acad. Sci. USA 101, 11040-11045.

Beresford, P., Barker, F.K., Ryan, P.G., Crowe, T.M., 2005. African endemics span the tree of songbirds (Passeri): molecular systematics of several evolutionary 'enigmas'. Proc. R. Soc. Lond. B 272, 849-858.

Bock, W.J., 1994. History and nomenclature of avian family-group names. Bull. Amer. Mus. Nat. Hist. 222, 1-281.

Bonaparte, C.L., 1850. Conspectus Generum Avium. E. J. Brill, Leiden.

Bonaparte, C.L., 1854. Conspectus systematis ornithologiae. Annales Sci. Naturelles (Paris), Zoologie, ser. 4, 105-152.

Brandley, M.C., Schmitz, A., Reeder, T.W., 2005. Partitioned Bayesian analysis, partition choice, and the phylogenetic relationships of scincid lizards. Syst. Biol. 54, 373-390. 
Brandley, M.C., Leaché, A.D., Warren, D.L., McGuire, J.A., 2006. Are unequal clade priors problematic for Bayesian phylogenetics? Syst. Biol. 55, 138-146.

Brumfield, R.T., Tello, J.G., Cheviron, Z.A., Carling, M.D., Crochet, N., Rosenberg, K.V., 2007. Phylogenetic conservatism and antiquity of a tropical specialization: army-ant-following in the typical antbirds (Thamnophilidae). Mol. Phylogenet. Evol. 45, 1-13.

Burmeister, H., 1837. Handbuch der Naturgeschichte. Zum Gebrauch bei Vorlesungen. Vol. 2. T. C. F. Enslin, Berlin.

Cabanis, J., 1847. Ornithologische Notizen. Archiv Naturgeschichte 13, 186-256 (pt. 1), 308-352 (pt. 2).

Chesser, R.T., 1999. Molecular systematics of the rhinocryptid genus Pteroptochos. Condor 101, 439-446.

Chesser, R.T., 2004. Molecular systematics of New World suboscine birds. Mol. Phylogenet. Evol. 32, 11-24.

Chesser, R.T., Brumfield, R.T., 2007. Tarphonomus, a new genus of ovenbird (Aves: Passeriformes: Furnariidae) from South America. Proc. Biol. Soc. Wash. 12, 337-339.

Chesser, R.T., Barker, F.K., Brumfield, R.T., 2007. Fourfold polyphyly of the genus formerly known as Upucerthia, with notes on the systematics and evolution of the avian subfamily Furnariinae. Mol. Phylogenet. Evol. 44, 1320-1332.

Cheviron, Z.A., Capparella, A.P., Vuilleumier, F., 2005. Molecular phylogenetic relationships among the Geositta miners (Furnariidae) and biogeographic implications for avian speciation in FuegoPatagonia. Auk 122, 158-174.

Cory, C.B., Hellmayr, C.E., 1925. Catalogue of birds of the Americas, Part IV. Field Mus. Nat. Hist. Zool. Ser. 13, 1-390.

Cracraft, J., 1974. Phylogenetic models and classification. Syst. Zool. 23, 71-90.

Cunningham, C.W., 1997a. Can three incongruence tests predict when data should be combined? Mol. Biol. Evol. 14, 733-740.

Cunningham, C.W., 1997b. Is congruence between data partitions a reliable predictor of phylogenetic accuracy? Empirically testing an iterative procedure for choosing among phylogenetic methods Syst. Biol. 46, 464-478.

Darlu, P., Lecointre, G., 2002. When does the incongruence length difference test fail? Mol. Biol. Evol. 19, 432-437.

Dolphin, K., Belshaw, R., Orme, C.D., Quicke, D.L.J., 2000. Noise and incongruence: interpreting results of the incongruence length difference test. Mol. Phylogenet. Evol. 17, 401-406.

Ericson, P.G.P., Irestedt, M., Johansson, U.S., 2003a. Evolution, biogeography, and patterns of diversification in passerine birds. J. Avian. Biol. 34, 3-15.

Ericson, P.G.P., Johansson, U.S., 2003b. Phylogeny of the Passerida (Ayes: Passeriformes) based on nuclear and mitochondrial sequence data. Mol. Phyl. Evol. 29, 126-138.

Ericson, P.G.P., Christidis, L., Cooper, A., Irestedt, M., Jackson, J., Johansson, U.S., Norman, J.A., 2002. A Gondwanan origin of passerine birds supported by DNA sequences of the endemic New Zealand wrens. Proc. R. Soc. Lond. B 269, 235-241.

Farris, J.S., Kallersjo, M., Kluge, A.G., Bult, C., 1994. Testing significance of incongruence. Cladistics 10, 315-319.

Farris, J.S., Kallersjo, M., Kluge, A.G., Bult, C., 1995. Constructing a significance test for incongruence. Syst. Biol. 44, 570-572.

Feduccia, A., 1973. Evolutionary trends in the Neotropical ovenbirds and woodhewers. Ornithol. Monogr. 13, 1-69.

Fjeldså, J., Irestedt, M., Ericson, P.G.P., 2005. Molecular data reveal some major adaptational shifts in the early evolution of the most diverse avian family, the Furnariidae. J. Ornithol. 146, 1-13.

Fjeldså, J., Irestedt, M., Jønsson, K.A., Ohlson, J.I., Ericson, P.G.P., 2007. Phylogeny of the ovenbird genus Upucerthia: a case of independent adaptations for terrestrial life. Zool. Scr. 36, 133-141.

Goloboff, P.A., Farris, J.S., Nixon, K.C., 2008. TNT, a free program for phylogenetic analysis. Cladistics 24, 774-786.

Gonzalez, J., Wink, M., 2008. Phylogenetic position of the monotypic Des Mur's Wiretail (Sylviothorhynchus desmursii, Aves: Furnarii- dae) based on mitochondrial and nuclear DNA. J. Ornithol. 149, 393-398.

Groth, J.G., Barrowclough, G.F., 1999. Basal divergences in birds and the phylogenetic utility of the nuclear RAG-1 gene. Mol. Phylogenet. Evol. 12, 115-123.

Guindon, S., Gascuel, O., 2003. A simple, fast and accurate algorithm to estimate large phylogenies by maximum likelihood. Syst. Biol. 52, 696-704.

Hackett, S.J., Rosenberg, K.V., 1990. Comparison of phenotypic and genetic differentiation in South American antwrens (Formicariidae). Auk 107, 473-489.

Hartlaub, G., 1853. Bericht Ober eine Sendung von Vogeln, gesammelt um Valdivia im siidlichtsten Chile durch Dr. Philippi. Naumannia 3, 207-222.

Huelsenbeck, J.P., Larget, B., Miller, R.E., Ronquist, F., 2002. Potential applications and pitfalls of Bayesian inference of phylogeny. Syst. Biol. 51, 673-688.

International Commission of Zoological Nomenclature, 1999. International code of zoological nomenclature, 4th edn. International Trust for Zoological Nomenclature, London. Available online at: http://www.iczn.org/iczn/index.jsp.

Irestedt, M., Johansson, U.S., Parsons, T.J., Ericson, P.G.P., 2001. Phylogeny of major lineages of suboscines (Passeriformes) analysed by nuclear DNA sequence data. J. Avian Biol. 32, 15-25.

Irestedt, M., Fjeldså, J., Johansson, U.S., Ericson, P.G.P., 2002. Systematic relationships and biogeography of the tracheophone suboscines (Aves: Passeriformes). Mol. Phylogenet. Evol. 23, 499-512.

Irestedt, M., Fjeldså, J., Nylander, J.A.A., Ericson, P.G.P., 2004a. Phylogenetic relationships of typical antbirds (Thamnophilidae) and test of incongruence based on Bayes factors. BMC Evol. Biol. 4, 23.

Irestedt, M., Fjeldså, J., Ericson, P.G.P., 2004b. Phylogenetic relationships of woodcreepers (Aves: Dendrocolaptinae) incongruence between molecular and morphological data. J. Avian Biol. 35, 280-288.

Irestedt, M., Fjeldså, J., Ericson, P.G.P., 2006. Evolution of the ovenbird-woodcreeper assemblage (Aves: Furnariidae) - major shifts in nest architecture and adaptive radiation. J. Avian Biol. 37, 260-272.

Isler, M.L., Lacerda, D.R., Isler, P.R., Hackett, S.J., Rosenberg, K.V., Brumfield, R.T., 2006. Epinecrophylla, a new genus of antwrens (Aves: Passeriformes: Thamnophilidae). Proc. Biol. Soc. Wash. 119, 522-527.

Isler, M.L., Isler, P.R., Whitney, B.M., Zimmer, K.J., 2007. Species limits in the "Schistocichla" complex of Percnostola antbirds (Passeriformes: Thamnophilidae). Wilson J. Ornithol 119, 53-70.

Kass, R.E., Raftery, A.E., 1995. Bayes factors. J. Am. Stat. Assoc. 90, 773-795.

Kauff, F., Lutzoni, F., 2002. Phylogeny of the Gyalectales and Ostropales (Ascomycota, Fungi): among and within order relationships based on nuclear ribosomal RNA small and large subunits. Mol. Phylogenet. Evol. 25, 138-156.

Krabbe, N.K., Schulenberg, T.S., 2003a. Family Formicariidae (Ground-Antbirds). In: del Hoyo, J., Elliott, A., Christie, D.A. (Eds.), Handbook of Birds of the World, Vol. 8: Broadbills to Tapaculos. Lynx Edicions, Barcelona, pp. 682-731.

Krabbe, N.K., Schulenberg, T.S., 2003b. Family Rhinocryptidae (Tapaculos). In: del Hoyo, J., Elliott, A., Christie, D.A., (Eds.), Handbook of Birds of the World, Vol. 8: Broadbills to Tapaculos. Lynx Edicions, Barcelona, pp. 748-787.

Lewis, P.O., Holder, M.T., Holsinger, K.E., 2005. Polytomies and Bayesian phylogenetic inference. Syst. Biol. 54, 241-253.

Lowery, G.H., O'Neill, J.P., 1969. A new species of antpitta from Peru and a revision of the subfamily Grallariinae. Auk 86, 1-12.

Messenger, S.L., McGuire, J.A., 1998. Morphology, molecules, and the phylogenetics of cetaceans. Syst. Biol. 47, 90-124.

Moyle, R.G., Chesser, R.T., Prum, R.O., Schikler, P., Cracraft, J., 2006. Phylogeny and evolutionary history of Old World suboscine birds (Eurylaimides). Am. Mus. Novit. 3544, 1-22. 
Nelson, G.J., 1972. Phylogenetic relationship and classification. Syst. Zool. 21, 227-231.

Nelson, G.J., 1973. Classification as an expression of phylogenetic relationships. Syst. Zool. 22, 344-359.

Nixon, K.C., 1999. The Parsimony Ratchet, a new method for rapid parsimony analysis. Cladistics 15, 407-414.

Nylander, J.A.A., 2004. MrModeltest v2. Program Distributed by the Author. Evolutionary Biology Centre, Uppsala University.

Nylander, J.A.A., Ronquist, F., Huelsenbeck, J.P., Nieves-Aldrey, J.L., 2004. Bayesian phylogenetic analysis of combined data. Syst. Biol. 53, 47-67.

Olson, S.L., Irestedt, M., Ericson, P.G.P., Fjeldså, J., 2005. Independent evolution of two Darwinian marsh-dwelling ovenbirds (Furnariidae: Limnornis, Limnoctites). Ornitologia Neotropical $16,347-359$.

Peters, J.L., 1951. Check-list of Birds of The World, Vol. 7. Museum of Comparative Zoology, Cambridge, MA, pp. 318.

Posada, D., Buckley, T.R., 2004. Model selection and model averaging in phylogenetics: advantages of the AIC and Bayesian approaches over likelihood ratio tests. Syst. Biol. 53, 793-808.

Posada, D., Crandall, K.A., 1998. MODELTEST: testing the model of DNA substitution. Bioinformatics 14, 817-818.

Raikow, R.J., 1994. A phylogeny of the woodcreepers (Dendrocolaptinae). Auk 111, 104-114.

Rannala, B., Yang, Z.H., 1996. Probability distribution of molecular evolutionary trees: a new method of phylogenetic inference. J. Mol. Evol. 43, 304-311.

Remsen, J.V., 2003. Family Furnariidae (Ovenbirds). In: del Hoyo, J., Elliott, A., Christie, D.A. (Eds.), Handbook of Birds of the World. Broadbills to Tapaculos, Vol. 8. Lynx Edicions, Barcelona, pp. 162-357.

Remsen, J.V. Jr, Cadena, C.D., Jaramillo, A., Nores, M., Pacheco, J.F., Robbins, M.B., Schulenberg, T.S., Stiles, F.G., Stotz, D.F., Zimmer, K.J., 2007 A classification of the bird species of South America. American Ornithologists' Union. Available online at: http://www.museum.lsu.edu/ ${ }^{\sim}$ Remsen/SACCBaseline.html.

Rice, N.H., 2005a. Phylogenetic relationships of antpitta genera (Passeriformes: Formicariidae). Auk 122, 673-683.

Rice, N.H., 2005b. Further evidence for paraphyly of the Formicariidae (Passeriformes). Condor 107, 910-915.

Ridgely, R.S., Tudor, G., 1994. The Birds of South America, Vol. 2. University of Texas Press, Austin, TX.

Ridgway, R., 1911. The birds of North and Middle America. Bull. U.S. Nat. Mus. 50, 1-859.

Ronquist, F., Huelsenbeck, J., 2003. MrBayes3: Bayesian phylogenetic inference under mixed models. Bioinformatics 19, 1572-1574.

Rudge, D.W., Raikow, R.J., 1992. The phylogenetic relationships of the Margarornis assemblage (Furnariidae). Condor 94, 760-766.

Sclater, P.L., 1862. Catalogue of a Collection of American Birds. N. Trubner \& Co., London.

Sclater, P.L., 1890. Catalogue of the Passeriformes, or Perching Birds, in the Collection of the British Museum. British Museum, London.

de Selys-Longchamps, M., 1839. Analyse d'une classification des oiseaux Passereaux, basée sur le genre de vie et sur les formes de ces oiseaux. Revueu Zoologique 2, 9-13.

Sibley, C.G., Ahlquist, J.E., 1985. Phylogeny and classification of New World suboscine passerine birds (Passeriformes: Oligomyodi: Tyrannides). Ornith. Monogr. 36, 396-430.

Sibley, C.G., Ahlquist, J.E., 1990. Phylogeny and Classification of Birds. Yale University, New Haven, CT.

Sibley, C.G., Monroe, B.L., 1990. Distribution and Taxonomy of Birds of the World. Phylogeny and Classification of Birds. Yale University Press, New Haven, CT.

Sibley, C.G., Ahlquist, J.E., Monroe, B.L. Jr, 1988. A classification of the living birds of the world based on DNA-DNA hybridization studies. Auk 105, 409-423.
Sikes, D.S., Lewis, P.O., 2001. PAUPRat: PAUP Implementation of the Parsimony Ratchet. Version 1. Distributed by the authors.

Sullivan, J., 1996. Combining data with different distributions of among-site rate variation. Syst. Biol. 45, 375-380.

Swainson, W., 1827. On several groups and forms in ornithology, not hitherto defined. Zool. Journ. 3, 343-363.

Swofford, D.L., 2003. PAUP*. Phylogenetic Analysis Using Parsimony (*and Other Methods). Sinauer Associates, Sunderland, MA.

Tello, J.G., Moyle, R.G., Marchese, D.J., Cracraft, J., 2009. Phylogeny and phylogenetic classification of the tyrant flycatchers, cotingas, manakins, and their allies (Aves: Tyrannides). Cladistics, doi: 10.1111/j.1096-0031.2009.00254.x.

Todd, W.E.C., 1927. New gnateaters and antbirds from tropical America, with a revision of the genus Myrmeciza and its allies. Proc. Biol. Soc. Wash. 40, 149-178.

Tostain, O., Dujardin, J.L., Érard, C., Thiollay, J.M., 1992. Oiseaux de Guyane. Société d'Études Ornithologiques, Brunoy, France.

Vaurie, C., 1971. Classification of the Ovenbirds (Furnariidae). H. F. \& G. Witherby, London.

Vaurie, C., 1980. Taxonomy and geographical distribution of the Furnariidae (Aves, Passeriformes). Bull. Am. Mus. Nat. Hist. 166, $1-357$.

Wetmore, A., 1930. A systematic classification for the birds of the world. Proc. US Natl. Mus. 76 (24), 1-8.

Wiley, E.O., 1979. An annotated Linnaean hierarchy, with comments on natural taxa and competing systems. Syst. Zool. 28, 308-337.

Wiley, E.O., 1981. Phylogenetics: The Theory and Practice of Phylogenetic Systematics. John Wiley, New York.

Willis, E.O., 1982. The behavior of Black-headed Antbirds (Percnostola rufifrons) (Formicariidae). Rev. Bras. Biol. 42, 233-247.

Wolters, H.E., 1977.Die Vogelarten der Erde [Fascicle 3]. Paul Parey, Hamberg.

Yang, Z., Rannala, B., 2005. Branch-length prior influences Bayesian posterior probability of phylogeny. Syst. Biol. 54, 455-470.

Yoder, A.D., Irwin, J.A., Payseur, B., 2001. Failure of the ILD to determine data combinability for slow loris phylogeny. Syst. Biol. $50,408-424$.

Zimmer, J.T., 1931. Studies of Peruvian birds. I. New and other birds from Peru, Ecuador, and Brazil. Am. Mus. Novit. 500, 1-23.

Zimmer, K.J., Isler, M.L., 2003. Family Thamnophilidae (Typical Antbirds). In: del Hoyo, J., Elliott, A., Christie, D.A. (Eds.), Handbook of the Birds of the World, Broadbills to Tapaculos, 8 . Lynx Edicions, Barcelona, pp. 448-681.

Zyskowski, K., Prum, R.O., 1999. Phylogenetic analysis of the nest architecture of Neotropical ovenbirds (Furnariidae). Auk 116, 891911.

\section{Supporting Information}

Additional Supporting Information may be found in the online version of this article:

Appendix S1. Samples used.

Appendix S2. Strict consensus of 7488 most parsimonious trees. Numbers at nodes represent bootstrap support values based on 5000 replicates, as described in the text.

Please note: Wiley-Blackwell are not responsible for the content or functionality of any supporting materials supplied by the authors. Any queries (other than missing material) should be directed to the corresponding author for the article. 